\title{
Ramularia leaf spot disease of barley is highly host genotype-dependent and suppressed by continuous drought stress in the field
}

\author{
Felix Hoheneder ${ }^{1} \cdot$ Katharina Hofer $^{1,3} \cdot$ Jennifer Groth ${ }^{2} \cdot$ Markus Herz $^{2} \cdot$ Michael Heß ${ }^{1,4} \cdot$ Ralph Hückelhoven $^{1}(\mathbb{D}$
}

Received: 10 June 2020 / Accepted: 17 December 2020 / Published online: 16 January 2021

(c) The Author(s) 2021

\begin{abstract}
Since the 1980s, Ramularia leaf spot (RLS) is an emerging barley disease worldwide. The control of RLS is increasingly aggravated by a recent decline in fungicide efficacy and a lack of RLS-resistant cultivars. Furthermore, climate change increases drought periods in Europe, enhances variable weather conditions, and thus will have an impact on severity of plant diseases. Hence, identification of RLS-resistant cultivars and understanding of disease progression under abiotic stress are important aims in integrated disease management under climate change. In the present study, we evaluated quantitative RLS resistance of 15 spring barley genotypes under drought, controlled irrigation and field conditions between 2016 and 2019 and monitored microclimatic conditions within the canopy. We identified genotypes that show robust quantitative resistance to RLS in different field environments. Our findings suggest that long-lasting drought periods create unfavourable conditions for the disease and supports that the extent and duration of leaf wetness is a key factor for RLS epidemics.
\end{abstract}

Keywords Ramularia collo-cygni $\cdot$ Spring barley $\cdot$ Climate change $\cdot$ Drought stress $\cdot$ Phenotyping $\cdot$ Leaf wetness

\section{Introduction}

Barley (Hordeum vulgare L.) is the fourth most important cereal crop plant worldwide, especially due to its robustness and adaptation to various and mostly restricted environments. On a global scale, about $85 \%$ of barley production is utilised for animal feed, whereas a small proportion is used for human consumption (Fischbeck 2002). Due to specific qualities of barley grain in favour of malting, it is commonly used for brewing beverages, which give high added values in the production and supply chain. Moreover, under wide span

Ralph Hückelhoven

hueckelhoven@wzw.tum.de

1 Chair of Phytopathology, TUM School of Life Sciences, Technical University of Munich, Freising-Weihenstephan, Germany

2 Institute for Crop Science and Plant Breeding, Bavarian State Research Center for Agriculture (LfL), Freising, Germany

3 Present Address: Plant Health and Environment Laboratory, Biosecurity New Zealand, Ministry for Primary Industries, Auckland, New Zealand

4 Present Address: German Environment Agency (Umweltbundesamt), Dessau, Germany of climate zones and very different growing conditions, barley possesses high yield potential and can be harvested after a comparatively short vegetation period. Thus, importance of barley will likely grow under increasingly unfavourable environmental conditions (e.g. increase in heat and drought) caused by a changing climate (Newton et al. 2011). However, as recently reported, global malt production is sensitive to climate change, which severely may affect future prices of barley and malt products (Xie et al. 2018).

Additionally, climate change is further driving important diseases in cereal crops, e.g. cereal rust, Fusarium Crown and Foot Rot (Luck et al. 2011; Delgado-Baquerizo et al. 2020). The shift of various climate factors like extreme and frequent precipitation events, drought or elevated mean temperature may directly and indirectly influence geographical appearance and distribution, seasonal phenology and further population dynamics of pathogens and pests (Chakraborty et al. 2000; Anderson et al. 2004; West et al. 2012; Juroszek and von Tiedemann 2013). From a field-scale view, climate and local weather are determining factors, which variously affect microclimate within canopy, the dynamics of inoculum spreading and infection process of a certain pathogen and further disease severity (Chakraborty et al. 2000; Luck et al. 2011). 
Additionally, the simultaneous occurrence of multiple stress factors is particularly fatal for crop production. It triggers different molecular pathways in stress-signalling resulting in a synergistic or antagonistic interaction of stresses which affect growth and plant defence (Pandey et al. 2015; Ramegowda and Senthil-Kumar 2015). Consequently, prediction about the occurrence and severity as well as management of emerging plant diseases (e.g. Ramularia Leaf Spot of barley) (Havis et al. 2015) is restricted and a challenge for crop production. Elevated risks are further aggravated by the predicted increase in variability in weather conditions and complex modifications in host-pathogen interactions, both driven by a changing climate system (Chakraborty et al. 2000; Atkinson and Urwin 2012). Improvement of host-resistance and utilization of genetic resources are effective, sustainable and promising tools to meet such challenges in future cereal crop production by cultivation of environmental robust and healthy crops.

The fungus Ramularia collo-cygni (Sutton and Waller) is the causal biotic agent of the Ramularia Leaf Spot (RLS) disease of spring and winter barley (Hordeum vulgare L.). The mitosporic ascomycete was first isolated and described in Italy in 1893 as Ophiocladium hordei (Cavara 1893) and later reclassified to Ramularia collo-cygni (Sutton and Waller 1988). Since the 1980s, R. collo-cygni drew increasing attention in agriculture and research, when unspecific necrotic leaf symptoms were first associated as a fungal disease (Sachs 2006). Since then, RLS is an emerging disease in barley causing increasingly economical relevant epidemics in several important barley growing countries in Europe and worldwide (Havis et al. 2015). Yield losses are attributed to a reduction of grain size. Average losses are recorded with $5-10 \%$, which can peak up to $75 \%$ on occasion (Pinnschmidt and Jørgensen 2009; McGrann and Havis 2017). Besides barley crops, Ramularia collo-cygni also infects other cereals like wheat (Triticum aestivum L.) (Huss 2004), triticale (Triticum $\times$ Secale) (Sutton and Waller 1988), oat (Avena sativa L.) (Huss 2004), rye (Secale cereale L.) (Huss and Miethbauer 2010), maize (Zea mays L.) (Huss 2008) and a broad range of grasses and weeds, though with lower economic impact (Huss 2004; Kaczmarek et al. 2017). The role of alternative hosts mediating as green bridge between spring and winter barley is still a matter of discussion, even though symptom formation is hardly conspicuous, except on barley. However, infection of different alternative hosts is not regularly observed, but infection of barley after spore flight from other crops and weeds was stated as highly probable. Sporulation found on infected maize could mediate as source of inoculum to infect young winter barley. (Huss 2004, 2008; Frei et al. 2007; Huss and Miethbauer 2010; Kaczmarek et al. 2017). Consequently, isolates from different hosts appear genetically admixed (Stam et al. 2019).
Symptoms occur mainly on upper leaves of barley in the late season post flowering and are associated with rapid leaf senescence. Furthermore, the fungus also infects tissues like culms, lemma, palea and in particular awns (Huss 2004). In contrast, the fungus asymptomatically colonizes the host plant during a relatively long endophytic stage in the early season. Originating from contaminated seeds, the pathogen is able to move upwards through the developing plant without causing symptoms, which was shown as an important route of host colonization (Matusinsky et al. 2011; Havis et al. 2014). At a later point in time, the fungus induces lesions, leaf senescence and the formation of spores exclusively occurring on necrotic tissue (Walters et al. 2008; Kaczmarek et al. 2017). From this stage, Ramularia collocygni switches to a necrotrophic lifestyle and becomes very dominant in the field. Important triggers for this switch in lifestyle are associated with the interaction of abiotic factors and host ontogenesis during generative phase of infected barley crops (Walters et al. 2008; Schützendübel et al. 2008; Newton et al. 2010). Thus, the question arises whether an increase in plant stress situations driven by climate change would enhance RLS disease outbreaks.

RLS symptoms are reddish to brown necrotic spots surrounded by a chlorotic halo and confined by leaf veins. The spots mainly develop on the sunlight-exposed sides of the leaf blade in an unspecific, speckle-like pattern and resemble physiological leaf spots (PLS). The interaction of abiotic stress factors, physiological imbalances in leaf tissue resulting in oxidative stress, cultivar dependent physiology and RLS cause together the leaf spot complex in barley. Both RLS and PLS components result in a reduction of green leaf area and reduce yield potential (Oxley et al. 2002; Sachs 2006; Heß et al. 2007; Schützendübel et al. 2008; Brown et al. 2014). Due to the fact that RLS can easily be confused with PLS and early small-sized spots of other necrotizing pathogens, i.e. Pyrenophora teres (net blotch), particularly PCR-based diagnostic methods have been developed. Such methods contribute to a clear detection and quantification of $R$. collo-cygni DNA in plant samples and seeds and can improve reliability of visual assessments in the field (Havis et al. 2006; Frei et al. 2007; Taylor et al. 2010). Both, RLS symptom formation and PLS directly coincide with maturation and further plant stress late in the season. In this context, the antioxidative defence system protects leaf tissue from an overload in reactive oxygen species (ROS) (Wu and von Tiedemann 2004; Schützendübel et al. 2008). Under normal conditions, ROS is involved in metabolism, plant defence signalling, ageing and whole plant ontogenesis (Apel and Hirt 2004), but during plant ripening, an imbalance in the antioxidative system is associated with the fungal production of light-dependent and photodynamic rubellins A, B, C and $\mathrm{D}$, released into the apoplast of infected barley leaves. Together with the secretion of other toxic compounds and 
cell wall degrading enzymes (Sjokvist et al. 2019), rubellins may cause a relatively delayed symptom formation (Heiser et al. 2003; Miethbauer et al. 2003, 2006). In addition, it was shown that secondary metabolites like polyketide synthases and peptide synthases expressed by $R$. collo-cygni are involved in early host colonization and during the development of early RLS symptoms on barley seedlings (Dussart et al. 2018).

Practices of Integrated Pest Management (IPM) including crop rotation, cultivation techniques (ploughing, support of decomposition of crop debris), disease monitoring and the choice of resistant varieties do not ensure a sufficient RLS control (Havis et al. 2018a, 2018b). Diverse studies suggested that full RLS resistance is absent from the barley gene pool and rather moderate susceptibility is what can be observed in comparative genotype surveys (Reitan and Salamati 2006; Mařík et al. 2011; Havis et al. 2015). Pinnschmidt and Sindberg (2007) could assess one almost symptomless winter barley cultivar in a multi-environment field testing of several spring and winter barley cultivars. However, such genotypes are still rare, though utilisation of RLS resistance seems not impossible. Breeding for RLS resistance is further complicated because production of $R$. collo-cygni spore inoculum in vitro and barley inoculation under controlled conditions are technically challenging (Makepeace et al. 2008; Sghyer and Hess 2019). Several studies revealed inconsistent results on a possible linkage of the mlo resistance locus effective against powdery mildew in barley (Blumeria graminis f.sp. hordei) and the level of susceptibility to R. collo-cygni and abiotic leaf spots (PLS) (Makepeace et al. 2007; Pinnschmidt and Sindberg 2007; McGrann et al. 2014; Hofer et al. 2015). In this context, it is also questionable whether the extended cultivation of mildew resistant mlo barley lines since the mid to late 1980s coincides with or caused the markedly emergence of RLS and the PLS in all important barley growing regions in Europe (Makepeace et al. 2007; McGrann et al. 2014; Havis et al. 2015). However, mlo mediated resistance against powdery mildew of barley is not employed in winter barley, whereas winter barley is similarly susceptible to $R$. collocygni (Jørgensen 1992; Makepeace et al. 2007; Czembor et al. 2016). Hence, mlo alone does not explain susceptibility of barley crops when compared to other small grain cereals.

Because fully resistant cultivars are not available, the control of RLS in barley is primarily based on chemical control by fungicides. A decline in fungicide efficacy up to a broad field resistance was recently observed in several European barley growing countries, concerning to major groups of fungicides: Thus, the control of RLS by quinone outside inhibitors (QoI), including strobilurins is hardly effective anymore against $R$. collo-cygni populations in some European countries, for example in United Kingdom, Denmark, Czech Republic and Germany (Fountaine and Fraaije 2009;
Matusinksy et al. 2010; Havis et al. 2015). With a shift to alternative products, a reduction in sensitivity of Ramularia isolates to demethylation inhibitors (DMI) and succinate dehydrogenase inhibitors (SDHI) followed in Western European Countries and in the UK (Piotrowska et al. 2017; Rehfus et al. 2019). The multi-site inhibitor chlorothalonil is solely a very effective chemical agent against RLS in cultivation of barley (Havis et al. 2018a). Nevertheless, the European Food Safety Association (EFSA) banned the use of chlorothalonil based fungicide products from 2020 onwards due to environmental safety concerns. Consequently, from the view of practical farming, effective management of RLS has to rely on alternative measures and disease control moves even more into the focus of an integrated approach.

The present study indicates the influence of late-terminal drought stress on the occurrence and severity of RLS in an assortment of 15 spring barley cultivars and current breeding lines, respectively. We used a rainout shelter to expose spring barley to drought stress under field conditions. Visual assessments of RLS, foliar diseases and the sporulation in the field reveal a general suppression of RLS under longlasting dry conditions. Furthermore, the determination of fungal DNA confirmed observations in the field. The data depicts great differences in RLS susceptibility between spring barley genotypes and identifies candidates for breeding RLS-resistant cultivars. We discuss potential effects of climate change along with drought conditions on RLS disease in Central Europe. The results support the understanding of the complex interaction between plant genotypes under stress conditions and the pathogenesis of RLS.

\section{Material and methods}

\section{Field trials under controlled drought stress}

For studies about the occurrence of RLS disease on droughtstressed spring barley under field conditions, a rainout shelter was used (moveable transparent polyvinyl roof with open fronts, size: approximately $12 \times 34 \mathrm{~m}$ ) at the Bavarian State Institute of Agriculture (LfL) in Freising (Southern Germany; soil: loamy-silt). The rainout shelter was equipped with a rain and wind sensor, to shield the field from rainfalls. Fifty-nine genotypes were sown twice in four blocks of randomized microplots (two rows with a length of $1 \mathrm{~m}$ ) in 2016 and 2017.

The blocks were regularly irrigated with $20 \mathrm{~mm}$ of water once a week by a permanently installed irrigation system $2 \mathrm{~m}$ above ground. The amount of irrigation was set according to long-time rainfall at the location in Freising. During GS 50 (approximately at the beginning of May), irrigation of two blocks was stopped to gain permanent drought stress (soil moisture tension below $-500 \mathrm{hPa}$ ) from the beginning 
of spike emergence to full maturing. The drought stress scenario was chosen to simulate prolonged dry periods during sensitive growth stages (e.g. flowering) late in the season, as expected in near future (Zebisch et al. 2005). The irrigated plots were continuously irrigated once a week. During periods of heat, the control plots were irrigated twice a week to maintain sufficient water supply as required. Soil moisture was monitored with tensiometers in depths of $15 \mathrm{~cm}, 45 \mathrm{~cm}$ and $75 \mathrm{~cm} 3$ times per week between begin of May and mid of July. Exemplary data of soil moisture tension in a depth of $45 \mathrm{~cm}$ are represented in Fig. $\mathrm{S} 1$.

Agronomic data of the 59 genotypes are provided in Table S1. The collection showed great variation concerning all determined traits. Significant differences were also found between the non-irrigated plots and the irrigated plots for most traits.

In season 2018, the assortment was narrowed down to 15 candidate genotypes showing variability in RLS resistance and furthermore stable performance and valuable agronomic traits under drought conditions in the two previous seasons (Table S1, highlighted genotypes). Due to a better comparability, only two-rowed and adapted genotypes combined with other favourable traits were selected. For example, genotypes "13/594/74", "Barke", "IPZ 24727" and "Marnie" had no reduced kernel size under drought stress. In addition, IPZ 24727 was used as reference line for stable performance under drought stress and high resistance to PLS, due to its background from German barley cultivars and a line of wild barley (H. spontaneum) originating from Israel (Behn et al. 2005; Lanzinger et al. 2015). "RGT Planet" and "STRG 706/16" were characterized by a high grain weight per double row in the non-irrigated plots. Genotypes with a high number of ear carrying stalks were "Argentinische DH 168", B0004", "Barke", "RGT Planet" and "STRG 706/16". Plants were grown in four randomized blocks consisting one field plot of each cultivar. Each plot had a size of 3.5 square metres $(1.5 \times 2.3 \mathrm{~m})$. The treatments "non-irrigated" and "irrigated" were performed as described above.

For reasons of consistency, only results of the 15 candidate genotypes for all the seasons are presented throughout the paper.

The plants were cover-sprayed once with $1.5 \mathrm{l} / \mathrm{ha}$ of the fungicide Input ${ }^{\circledR}$ Xpro (Bayer Crop Science) approximately at growth stage 39 to control commonly occurring foliar diseases. Fertilization, insecticides and herbicides were used according to standard agricultural practises. Therefore, 80 to $100 \mathrm{~kg} \mathrm{~N} / \mathrm{ha}$ were applied by the use of ammonium sulphate fertilizer during tillering. After full ripening (GS 99), micro plots were harvested and threshed manually, macro plots were harvested with a single plot combine harvester. Sowing dates, recorded growth stages and dates of harvest of each year are listed in Table S2 (supplements).

\section{Additional field trials}

A second location at Weihenstephan (Freising, South Germany; soil: loamy-silt), about $1.5 \mathrm{~km}$ away from the rainout shelter was used to assess natural infection of $R$. collo-cygni and RLS disease progression. Therefore, 59 spring barley genotypes were sown in microplots (two rows of plants with a length of $1 \mathrm{~m}$ ) in 2016 and 2017. In the seasons 2018 and 2019, 15 candidate genotypes (Table S1) of the assortment were sown in standard field plots (size $1.5 \times 7.5 \mathrm{~m}$ ), respectively.

Plants were cover-sprayed once with $0.81 /$ ha of the fungicide Prosaro ${ }^{\circledR}$ (Bayer Crop Science) at GS 32 to control other foliar diseases except Ramularia collo-cygni. Fertilizer and herbicides were used in regard to standard agricultural practise. According to soil nitrogen content, 80 to $100 \mathrm{~kg} \mathrm{~N} / \mathrm{ha}$ were applied by the use of ammonium sulphate fertilizer during tillering. After full ripening (GS 99), micro plots were harvested and threshed manually, macro plots were harvested with a plot combine harvester. Dates of sowing, recorded growth stages and harvest of each year are listed in Table S2 (supplements).

For the estimation of yield and stability of performance, the entire assortment was planted in macro plots ranging from 6.3 to 11.3 square metres in six additional environments (three locations in Bavaria, one in Lower Saxony, one in Saxony-Anhalt and one in France) in the season 2018. Plants were grown in two randomized blocks at each location. Fertilization and pesticide treatments were performed according to local agricultural practises. As mentioned above, only the results of the 15 genotypes of the narrowed assortment are presented and discussed in this paper.

\section{Weather conditions and microclimate within plant canopy}

Average temperature, sum of precipitation and leaf wetness was recorded by weather station in Freising during the seasons 2016 to 2019. The data were assessed from the agro-meteorology web portal of the Bavarian State Institute of Agriculture (Agrarmeteorologie Bayern 2020). In addition, data logger (HOBO $®$ Pro v2 data logger, Onset, MA, USA) was placed within the plant canopy to measure on-site temperature and relative humidity and to automatically calculate the temperature of the dew point in a time interval of one hour. Data logger information was extracted by the HOBOware Pro software system (Onset, MA, USA). Mean values were calculated for each week during the growing season. 


\section{Assessment of symptoms or sporulation and leaf sampling}

To examine foliar disease infestation with focus on Ramularia leaf spot and physiological leaf spots, a visual assessment of all common foliar diseases of barley was conducted at early to mid-dough stage (growth stage 83-85). Physiological leaf spots (PLS) and Ramularia leaf spots (RLS) were summed up as a leaf spot complex due to unspecific differentiation in the field. For accurate determination of RLS and sporulation, up to 10 flag leaves (F) and the leaf stage below (F-1) were randomly sampled from each cultivar at growth stage 83 to 85 in both trials. Leaves were stored at $-20{ }^{\circ} \mathrm{C}$ until further processing.

Sporulation was assessed by the use of a binocular microscope at a maximum magnification of 40 and bright light from side in a flat angle. Therefore, clusters of sporangiophores on the bottom side of several leaves were examined. Sporulation was determined as mean leaf area with visible sporangiophores in percent in consideration of variable leaf size, which was visually estimated. At least ten leafs per genotype were assessed.

\section{Isolation of genomic DNA from leaf material}

Genomic DNA was extracted according to the protocol of Fraaije et al. (1999) including minor modifications as published by Hofer et al. (2016). Therefore, all sampled leafs were ground to fine powder by the use of liquid nitrogen and a 2-ml reaction tube was filled approximately with $250 \mathrm{mg}$ sample for subsequent DNA extraction. DNA concentration (ng total DNA $\mathrm{Il}^{-1}$ ) and quality were measured by the use of a NanoDrop ${ }^{\circledR}$ ND-1000 spectrophotometer (Thermo Fisher Scientific, MA, USA). In a final step, the samples were adjusted to a concentration of $20 \mathrm{ng}$ total DNA $\mu \mathrm{l}^{-1}$ with sterile double-distilled water. Extracted DNA samples were stored at $4{ }^{\circ} \mathrm{C}$ until further processing.

\section{Quantification of R. collo-cygni DNA}

$R$. collo-cygni DNA was quantified by a real-time quantitative polymerase chain reaction (qPCR) following a Taq-Man qPCR protocol according to Taylor et al. (2010). The PCR amplification was performed by the use of an MX3005P Multiplex Quantitative PCR System (Stratagene, CA, USA). Data analysis was carried out with MxPRO qPCR software (Stratagene, CA, USA).

\section{Calculation of disease severity ranking}

To evaluate the resistance to RLS in manner, which balances year-effects of disease severity, a ranking list was calculated to transcribe assessed disease values to explicit ranks. The mean ranking of each assessed disease parameter (mean ranking for symptomatology, sporulation and DNA contents) and a total mean rank was calculated for each genotype and year (minimum rank: 1; maximum rank 15) and then averaged over years. Therefore, each single value was sorted in an ascending order and assigned to one rank for each disease parameter. Low ranks indicate resistance and were equal to low values; high ranks indicate susceptibility and were equal to high values. Shared ranks were scored with same single value.

\section{Stability analysis}

In order to determine the stability of genotypes according to yield parameters across environments, the additive main effect and multiplicative interaction (AMMI) model was used. It fits the additive effects for genotypes and environments and multiplicative terms for genotype $\mathrm{x}$ environment interactions (Crossa et al. 1990). AMMI stability values (ASV) were calculated for each of the 15 genotypes according to Purchase et al. (2000) to rank genotypes according to trait stability. The lower the ASV, the more stable is a genotype. The calculated yield parameter stability index (YPSI) is based on summing the ranking of overall mean performances for each trait and the ranking for ASV for each trait. The YPSI was calculated as follows:

$\mathrm{YPSI}_{\mathrm{i}}=\mathrm{RASV}_{\mathrm{i}}+\mathrm{RY}_{\mathrm{i}}$

where YPSI $_{\mathrm{i}}$ : yield parameter stability index for the $\mathrm{i}^{\text {th }}$ genotype across seasons/treatments; RASV $V_{i}$ : rank of the $i^{\text {th }}$ genotype across seasons/treatments based on ASV; $\mathrm{RY}_{\mathrm{i}}$ : rank of the $\mathrm{i}^{\text {th }}$ genotype based on mean performance across seasons/ treatments. Beside of yield, the traits of interest were fraction of kernels with a size $>2.5 \mathrm{~mm}$, fraction of kernels with a size $>2.8 \mathrm{~mm}$ and thousand kernel weight (TKW), which are relevant parameters under the aspect of malting quality of barley. The yield parameters were assessed for the 15 genotypes in the rainout shelter experiment, our own field trial and six additional field locations in Germany and France in 2018. YPSI ranks of each genotype were summed for all traits and the genotype with the smallest rank sum was considered to be the best across traits.

The AMMI analysis as well as the stability values (ASV) and indices (YPSI) was calculated using $\mathrm{R}$ version 3.5.2. (www.r-project.org) and the package agricolae (De Mendiburu and Simon 2015).

\section{Results}

\section{Evaluation of Ramularia resistance under irrigated and drought conditions}

For determination of basal resistance to RLS of several spring barley genotypes, we assessed disease severity after 
A

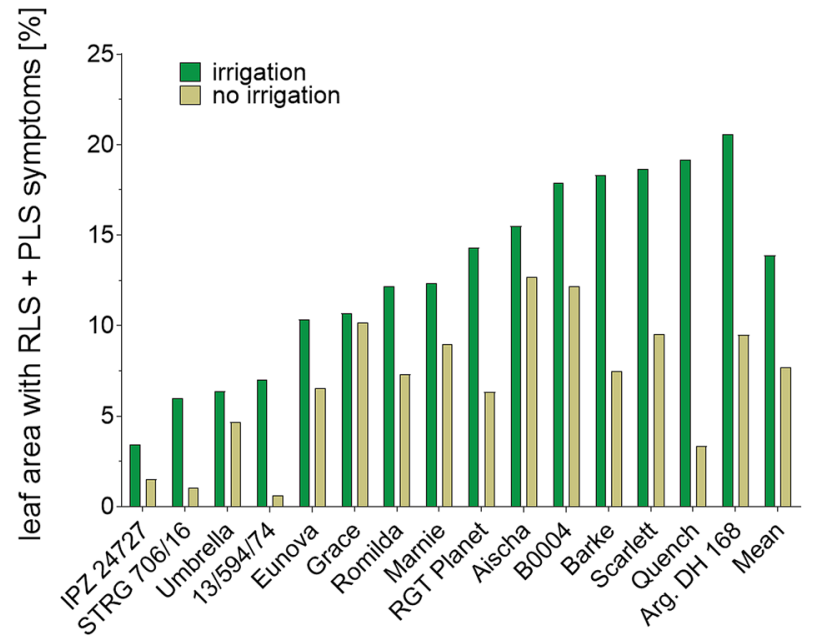

C

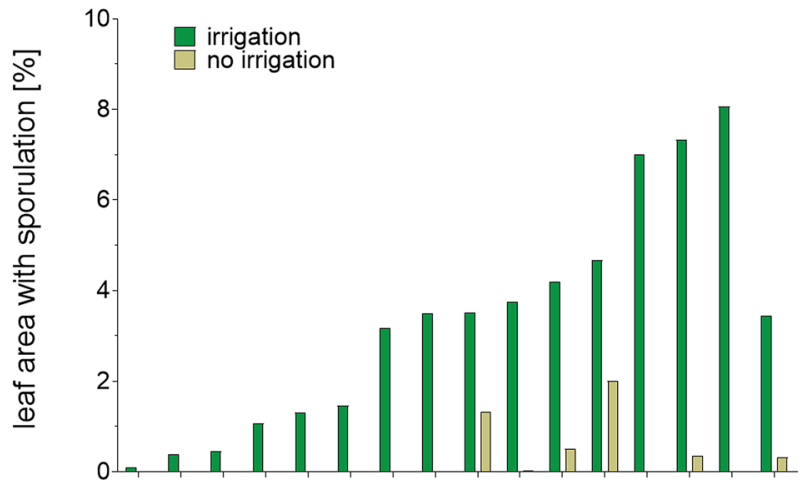

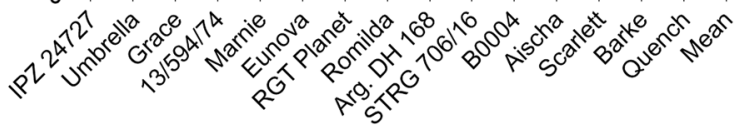

E

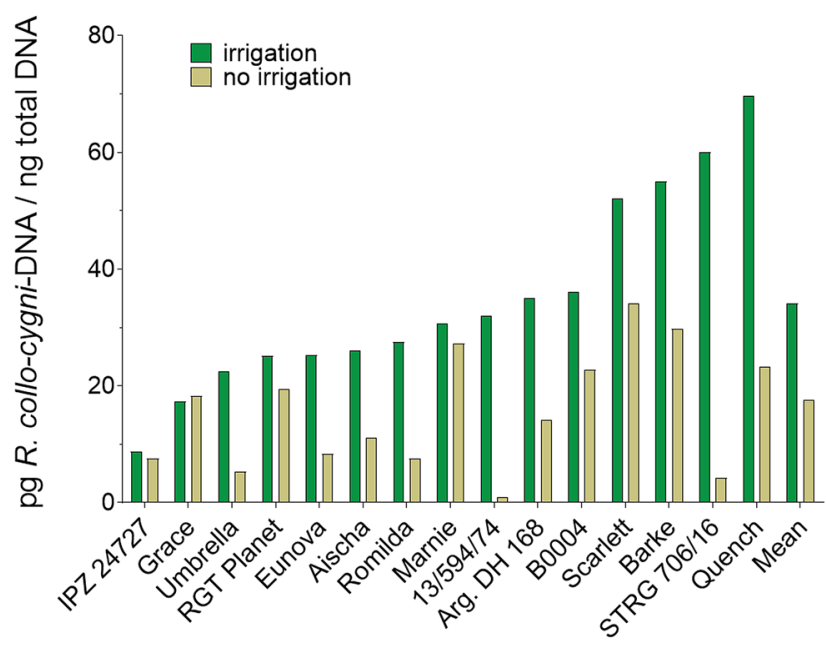

B

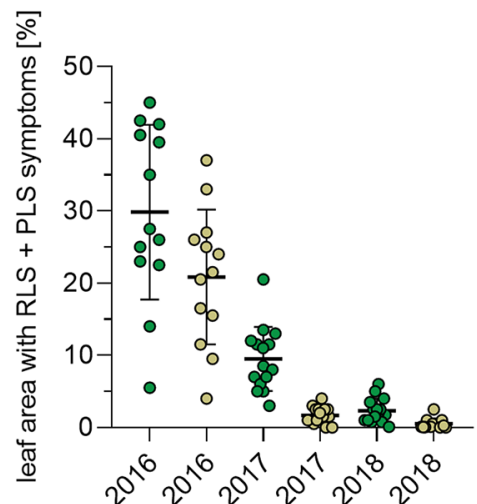

D

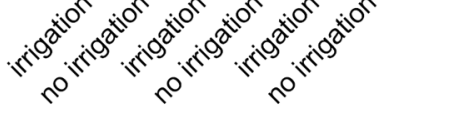

F
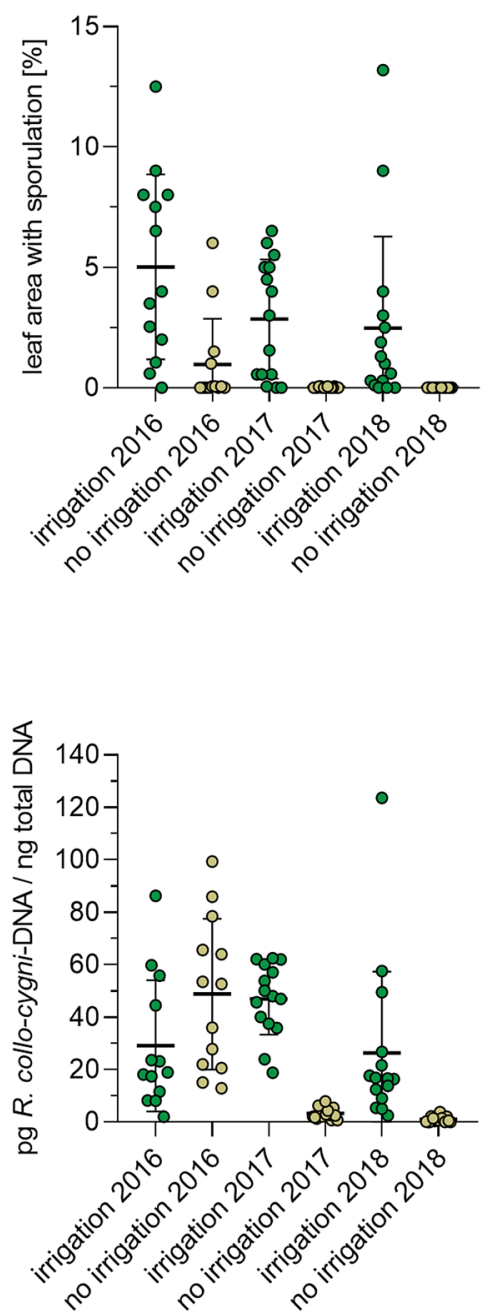
4Fig. 1 Levels of Ramularia leaf spot infestation according to assessed disease parameters under drought stress and irrigation in the rainout shelter experiment between 2016 and 2018. The bars indicate calculated mean values of three years. a represents percentage of leaf area with Ramularia and physiological leaf spots. $\mathbf{c}$ indicates percentage of leaf area with sporulation. e shows detected values of RamulariaDNA in pg Rcc DNA/ng total DNA. b, $\mathbf{d}$ and $\mathbf{f}$ show single values and the total mean of each disease parameter under irrigation and under drought stress for each season. Error bars indicate the standard deviation of the mean

natural infection by three diagnostic tools on samples from either the field or from a rainout shelter. (1) We rated the leaf area with RLS symptoms and plant stress related PLS together (RLS + PLS), because symptoms are difficult to differentiate without microscopy. Therefore, the data illustrate the Ramularia leaf spot complex of barley. (2) In parallel to visual assessment, leaf samples (flag and flag-1 leaf) were collected to examine leaf area with sporulation of Ramularia collo-cygni with the help of a stereo microscope. (3) Additionally, genomic DNA was extracted from flag and flag-1 leaf samples to assess the development of $R$. collo-cygni in upper leaves (Fig. 1a, c and e). We used an assortment of 15 two-rowed spring barley genotypes, which were preselected from bigger assortment for high and stable yield, homogenous plant height, similar heading date and largely high performance in different field environments and under drought stress (see Table S1, and material and methods).

In the rainout shelter, we compared irrigated plots with plots under permanent drought stress from GS 50 onwards over three consecutive years from 2016-2018. The genotypes growing under irrigation showed a strong differentiation in RLS severity. Noticeable symptoms were found on upper leaves, which also reflected fungal DNA contents and sporulation. Under drought, all tested 15 genotypes were less severely infected with $R$. collo-cygni and showed less RLS symptoms when compared to the irrigated plots. RLS was in general the dominating foliar disease in the irrigated plots and under drought (Fig. S2). The results revealed a general decrease in Ramularia disease after application of drought stress between spike emergence and full ripening stage over three consecutive years: symptomatology, sporulation and DNA contents in the upper leaves were largely corresponding to each other (Fig. 1a, f and 2). A Pearson's correlation revealed a significant correlation between leaf area with sporulation and with Ramularia-DNA and leaf area with sporulation and RLS symptoms under irrigation. RLS symptoms significantly correlated with RamulariaDNA contents and leaf area with sporulation under drought conditions (Fig. 2).

Mean levels of symptomatic leaf area ranged between 3.4\% (breeding line IPZ 24727) and 20.5\% (Argentinische DH 168) in the irrigated plots. Under drought stress, the highest mean of symptomatic leaf area was $12.6 \%$ (Aischa), the lowest recorded mean area was $0.6 \%$ (breeding line 13/594/74). Symptomatic leaf area of cultivar Grace was almost equal in the irrigated plants compared to plants growing under drought stress (irrigation: 10.7\%; drought stress: 10.2\%) (Fig. 1a).

Leaf area with visible $R$. collo-cygni sporulation did not exceed $8.1 \%$ under irrigation. The genotypes Quench, Barke and Scarlett showed the highest rates of sporulation $(8.1 \%$, $7.3 \%$ and $7 . \%)$. Little sporulation $(<1 \%)$ was found for the genotypes IPZ 24727, Umbrella and Grace, followed by breeding line 13/594/74 (1.1\%), Marnie (1.3\%) and Eunova (1.5\%) (Fig. 1c).

Under drought stress conditions, we detected sporulation only on 9 out of 15 genotypes. Mean values remained below $2.0 \%$ (Aischa). On leaves of Grace, RGT Planet, Marnie, Scarlett, Eunova and 13/594/74, no sporulation was recorded under drought conditions (Fig. 1c).

Contents of Ramularia-DNA differed among the tested genotypes in a range between 8.5 and $87.3 \mathrm{pg} / \mathrm{ng}$ total DNA (factor of 10.3) in the irrigated plots. Under these conditions, highest average DNA content (69.6 pg/ng total DNA) was found in leaves of Quench and the lowest average content ( $8.8 \mathrm{pg} / \mathrm{ng}$ total DNA) in IPZ 24727 (Fig. 1e).

Mean DNA contents of drought-stressed genotypes remained below the contents in the corresponding irrigated plants, except for Grace (irrigation $17.4 \mathrm{pg} / \mathrm{ng}$ total DNA; drought stress: $18.3 \mathrm{pg} / \mathrm{ng}$ total DNA). DNA contents ranged between $0.9 \mathrm{pg} / \mathrm{ng}$ total DNA for 13/594/74 and $34.1 \mathrm{pg} / \mathrm{ng}$ total DNA in Scarlett under drought conditions. The most noticeable differences of fungal DNA contents between irrigated conditions and drought stress accounted for the breeding lines STRG 706/16 (irrigation: $60.0 \mathrm{pg} / \mathrm{ng}$ total DNA; no irrigation: $4.2 \mathrm{pg} / \mathrm{ng}$ total DNA) and 13/594/74 (irrigation: $32.0 \mathrm{pg} / \mathrm{ng}$ total DNA; no irrigation: $0.9 \mathrm{pg} / \mathrm{ng}$ total DNA) (Fig. 1).

A comparison of single years revealed strong variations in RLS severity in the rainout shelter over the three years (Fig. 1b, d, f). RLS and PLS symptoms predominantly occurred in 2016 (total mean, irrigation: 29.8\%; total mean, drought conditions: $20.8 \%$ ). In 2017, total mean leaf symptoms did not exceed 9.5\% (irrigation) and $1.7 \%$ (drought conditions), respectively, and remained below $2.3 \%$ in the irrigated plots in 2018 (Fig. 1b). Variation in total mean of leaf area with sporulation was comparable to leaf symptoms across single years. Total mean leaf area with sporulation was highest under irrigation in 2016 (5.0\%), followed by 2017 (2.9\%) and 2018 (2.5\%). Under drought conditions, sporulation was only detected in 2016, where mean sporulating leaf area reached 1\% (Fig. 1d). Mean Ramularia-DNA contents in upper leafs of plants under irrigation were highest in 2017 (47 pg/ng total DNA), followed by $29.1 \mathrm{pg} / \mathrm{ng}$ total DNA in 2016 and $26.3 \mathrm{pg} / \mathrm{ng}$ total DNA in 2018. The highest mean DNA content was measured in upper leafs 
A

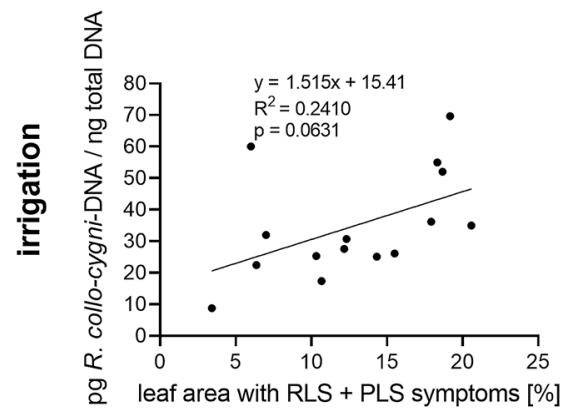

B

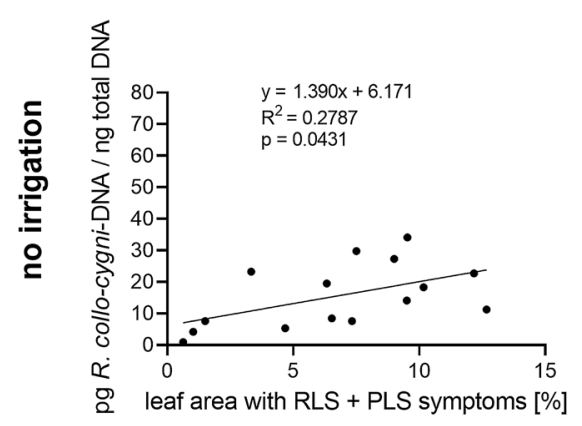

C

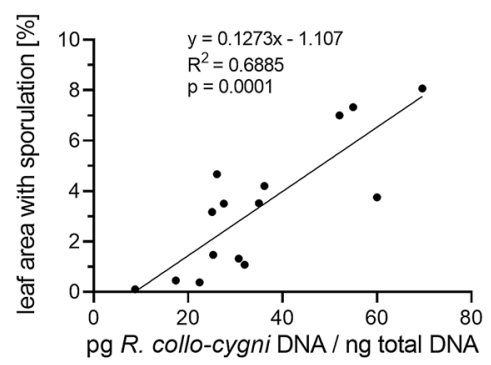

$\mathrm{D}$

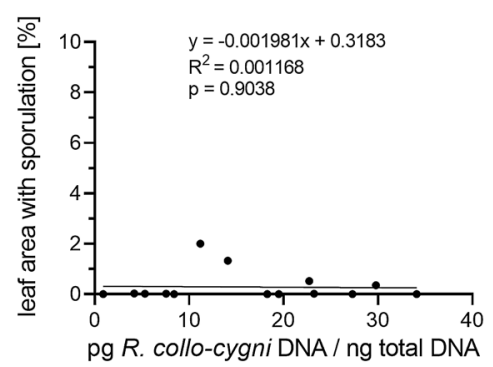

$\mathrm{E}$

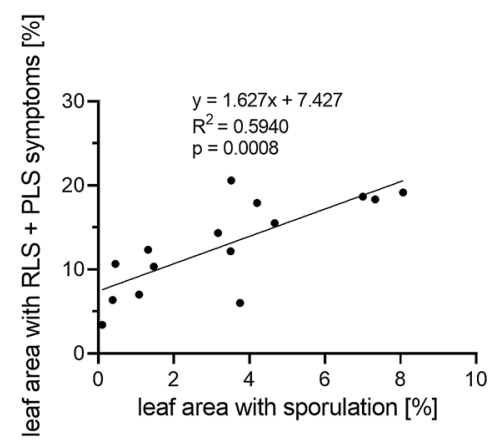

F

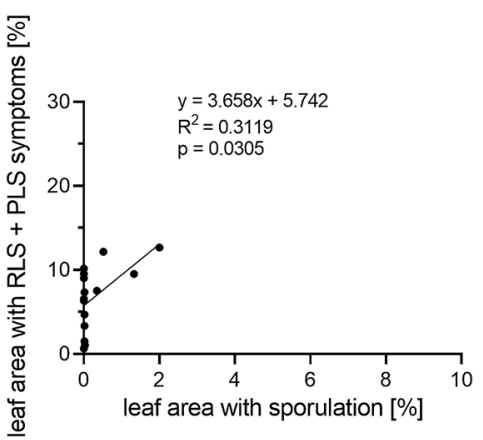

Fig. 2 Relations between assessed Ramularia leaf spot disease parameters in the rainout shelter between 2016 and 2018. Data points represent calculated means of 15 spring barley genotypes. RLS and PLS symptoms and Ramularia-sporulation are presented as percentage of leaf area, respectively. Visual assessment of upper leaves was conducted at growth stage 83-85. Statistical analysis: linear regression; $p$ value indicates significance of the slope from zero

168 ranked highest in terms of RLS severity under drought stress.

Taken together, the data reveal a general decrease in Ramularia collo-cygni infection rates and suppression of sporulation in the drought-stressed barley plants when compared to the irrigated plants. Moreover, the assortment of cultivars and current breeding material showed strong differentiation in the level of quantitative resistance against RLS. Differentiation of RLS resistance was more pronounced under irrigation when compared to non-irrigated conditions. Particularly, the genotypes IPZ 24727 and Umbrella were little affected by RLS disease under both conditions.

\section{Monitoring of microclimatic conditions under drought and irrigation}

We used data loggers to measure average temperature, average relative air humidity and the dew point temperature within the canopy for investigation of effects of drought on microclimate. Measurements were taken between first week of June and fourth week of July in 2017 and 2018. The data are represented as weekly average (Table 1).

During growth period in 2017, the mean temperature under dry conditions was increased by $1.3{ }^{\circ} \mathrm{C}$ when compared to 
A

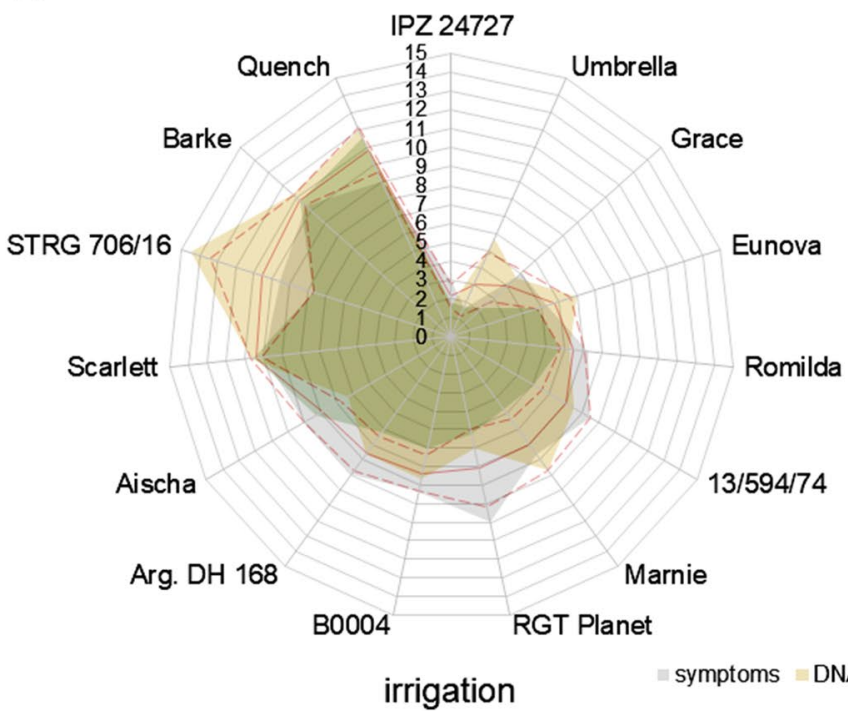

Fig. 3 Disease severity ranking according to assessed disease parameters in the irrigated plants $\mathbf{a}$ and under drought stress $\mathbf{b}$ in the rainout shelter experiment between 2016 and 2018. The radar plots show mean ranks over the 3 years for each disease parameter. The red line indicates the total mean rank over three years and three disease parameters ( $n=9$ ranks per genotype); dashed red lines indicate

the irrigated plots. At several points in time, the difference in mean temperature exceeded a range of 0.8 to $1.9^{\circ} \mathrm{C}$ in 2017 between anthesis (mid of June) to full ripening (third to fourth week of July). Between the first week of June (GS 50: spike emergence) and third week of July (GS 99: grain maturity) in 2018, the drought-induced differences in mean temperature was between 1.4 and $2.9^{\circ} \mathrm{C}$. In both seasons, increased average temperature was accompanied by a lower relative air humidity in the canopy without irrigation. Total average air humidity in the irrigated plots was about $80 \%(80.5 \%, 82.0 \%)$ in both seasons during the recorded period. The difference in average relative air humidity amounted to $13.8 \%$ (2017) and $16.4 \%$ (2018) between irrigated and drought conditions, respectively. Accordingly, the total mean dew point temperature was higher in the irrigated plots by $1.9^{\circ} \mathrm{C}$ in 2017 and by $1.8^{\circ} \mathrm{C}$ in 2018 , respectively.

\section{Monitoring of leaf wetness in the rainout shelter experiment}

In addition to microclimate measurements, we monitored leaf wetness every $10 \mathrm{~min}$ in the canopy of the irrigated plots and in the non-irrigated plots in the season of 2017 (Fig. 4). Data were further used to calculate daily average leaf wetness. During the monitored time frame, the mean leaf wetness was significantly higher under irrigation $(60.0 \%)$ than in the non-irrigated plots $(14.2 \%)$ (Fig. 4a). The progression of leaf wetness revealed higher
B

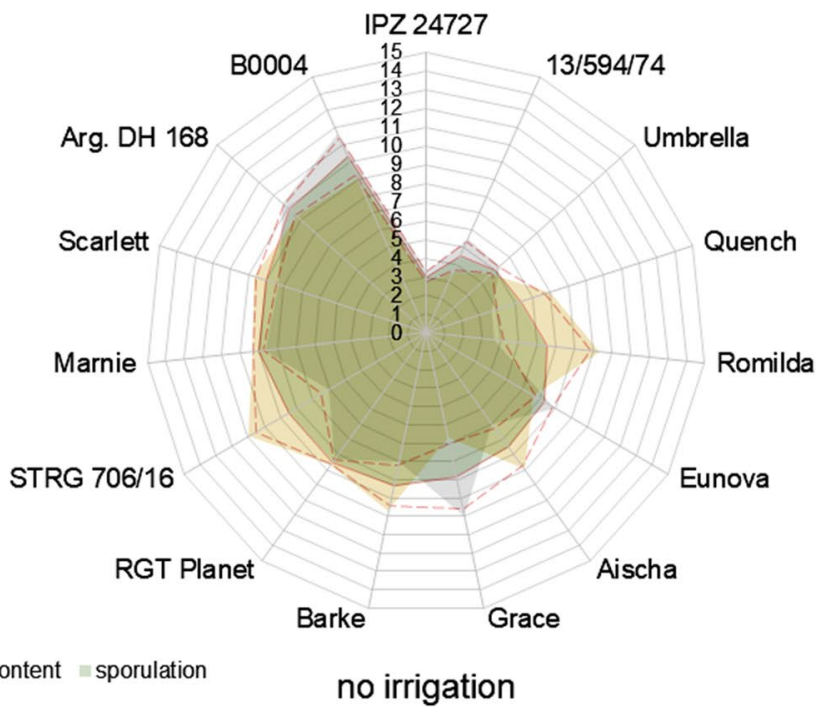

positive and negative standard deviation of the mean. The genotypes are sorted clockwise by total mean rank whereby low ranks indicate quantitative resistance and high ranks indicate higher susceptibility to RLS. Individual ranks are in a range of minimum 1 and maximum 15. If two or more genotypes share the same rank, the same value was associated to those lines

fluctuating average leaf wetness in the irrigated plots (18.8-100.0\%) compared to the plants growing under drought (3.8-38.4\%). Furthermore, mean leaf wetness in the non-watered plots never reached the level that was simultaneously recorded in irrigated plots (Fig. 4b). This shows that the applied drought conditions strongly influenced the microclimate in the canopy and leaf wetness.

Furthermore, the mean leaf wetness duration (LWD) was calculated according to different categories of leaf wetness between $100-81,80-51,50-21$ and $20-0 \%$ and is presented in Fig. 4c. Highest mean LWD was recorded for the category above $81 \%$ in the irrigated control (465 min). No data points appeared in that category under non-irrigated conditions. Vice versa, under drought conditions, the mean LDW in the category below $20 \%$ leaf wetness was 1027 min but only 367 min under irrigated conditions. In the intermediate leaf wetness categories, there was a less strong difference between irrigated and non-irrigated plots. Hence, experimental conditions caused high and long-lasting leaf wetness under irrigation but even longer periods of relative low leaf wetness without irrigation.

\section{Monitoring of drought application in the rainout shelter}

Tensiometers were used to assess water demand and drought conditions of the barley plants in the rainout shelter. Therefore, we measured soil moisture tension three times per week 


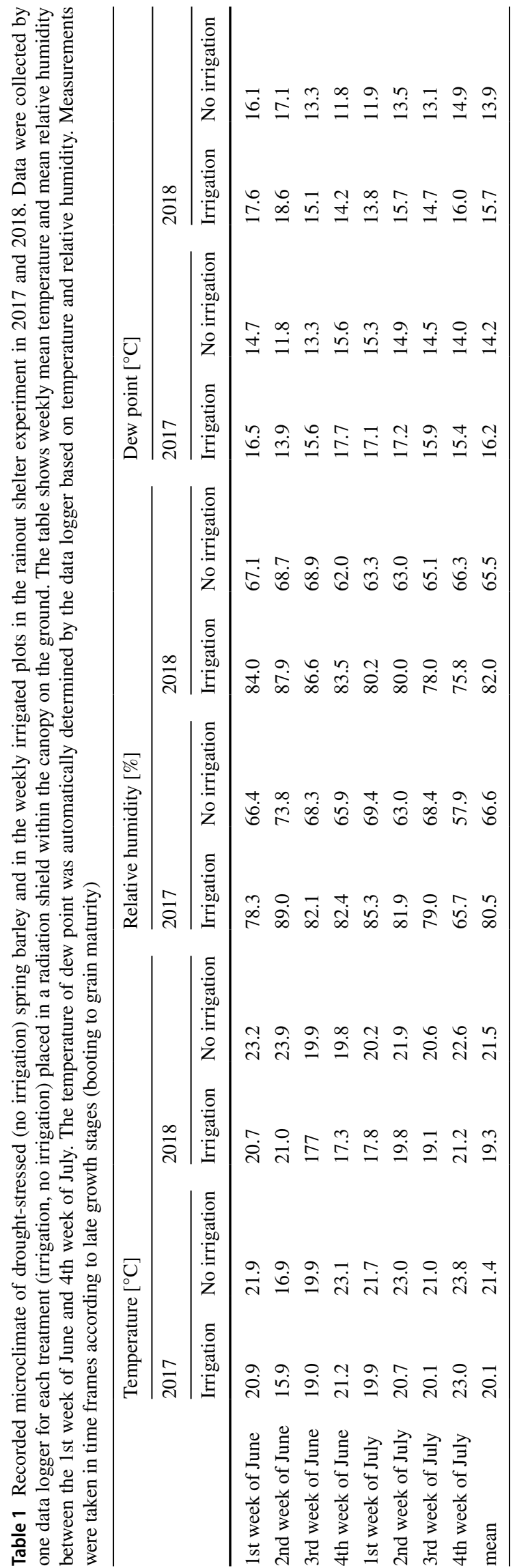

in a depth of 15, 45 and $75 \mathrm{~cm}$ in the irrigated plots and the plots without irrigation. Exemplary data of soil moisture tension in a depth of $45 \mathrm{~cm}$ are presented in supplemental Fig. S1. A soil moisture tension below $-500 \mathrm{hPa}$ was referred as drought. Such drought conditions were obtained by a stop of irrigation at the beginning of May. Data show a subsequent reduction in soil moisture, resulting in a soil water potential below $-500 \mathrm{hPa}$ at end of May in 2016 to 2018. During June and July, average soil moisture tension remained below $-500 \mathrm{hPa}$ in non-irrigated plots in all three seasons indicating successful establishment of permanent and long-lasting drought conditions.

\section{Evaluation of Ramularia resistance under field conditions}

In addition to the rainout shelter experiments, we conducted a 4 year field plot trial (between 2016 and 2019) to evaluate the natural RLS infection of the same 15 spring barley genotypes. The examined symptoms are shown as mean percentage of leaf area with RLS + PLS symptoms (Fig. 5a). Symptomatic leaf areas of the upper leaves varied between 19.4 and $33.6 \%$ with apparent differences between the genotypes. Least symptoms appeared in the genotype Argentinische DH 168 followed by RGT Planet (21.4\%), IPZ 24727 (21.5\%) and Marnie (22.0\%). High percentage of affected leaf areas were recorded for Quench, Romilda (32.5\%) and Aischa (31.9\%). Total mean of symptomatic leaf area across the 15 genotypes was $26.3 \%$. Rates of RLS symptoms varied between seasons and was highest in 2016 (total mean: 45.3\%), followed by 2018 (32.3\%) and 2017 (20.8\%). Least RLS symptoms occurred in 2019 (total mean: 6.9\%). In all four seasons, RLS was the dominant foliar disease over net blotch and brown rust, which both occurred at a low level (Fig. S4).

In addition to visual assessments, we evaluated leaf samples for fungal sporulation and DNA contents in the upper leaves in 2018 and 2019. The mean percentage of leaf area with visible sporulation ranged between $10.1 \%$ in Grace and $48.7 \%$ in Aischa. Total mean of the 15 genotypes was at $27.0 \%$ of the leaf area showing sporulation. A high variation in total mean was observed between the 2 years (2018: 53.3\%; 2019: 0.6\%). (Fig. 5b). The average content of $R$. collo-cygni-DNA in the upper leaves varied between 9.3 (13/594/74) and 167.0 (Aischa) pg/ng total DNA, which resembles a factor of 18 . Besides for breeding line 13/594/74, relatively low DNA contents were also detected in Eunova (19.0 pg/ng total DNA) and Scarlett (20.6 pg/ng total DNA). The total mean of DNA contents (100.1 pg/ng total DNA) was determined from a mean of 142.4 and $57.9 \mathrm{pg} / \mathrm{ng}$ total DNA in 2018 and 2019, respectively, which indicates variation in RLS infestation between the two seasons (Fig. 5c). 
Fig. 4 Mean leaf wetness of drought-stressed plants compared with irrigated plants monitored between 26 June and 08 August 2017 a, progression of leaf wetness $\mathbf{b}$ and mean leaf wetness duration $\mathbf{c}$ in the rainout shelter experiment. The data are presented as daily mean of leaf wetness and mean leaf wetness duration in minutes for leaf wetness between 100-81 $\&, 80-51 \%, 50-21 \%$ and below $20 \%$. Error bars indicate the standard deviation of the mean. Measurements were taken in a 10-min interval by two leaf wetness sensors in the canopy one meter above ground. Statistical analysis: Unpaired Welch $t$ test $(p<0.0001)$
A

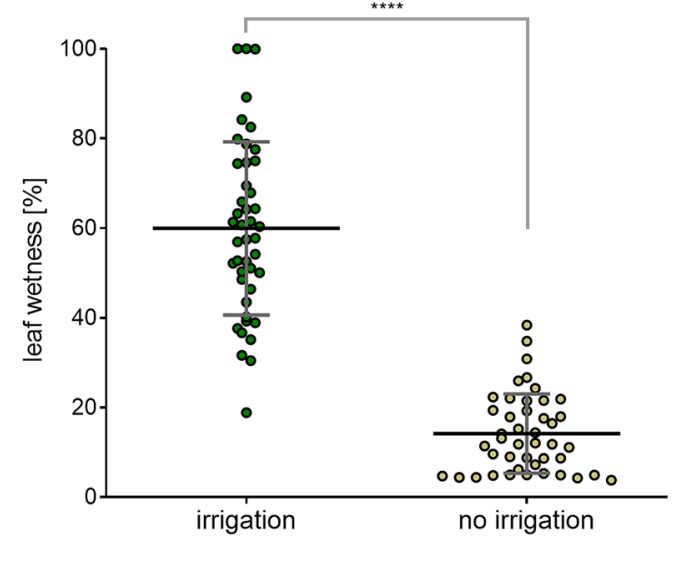

C

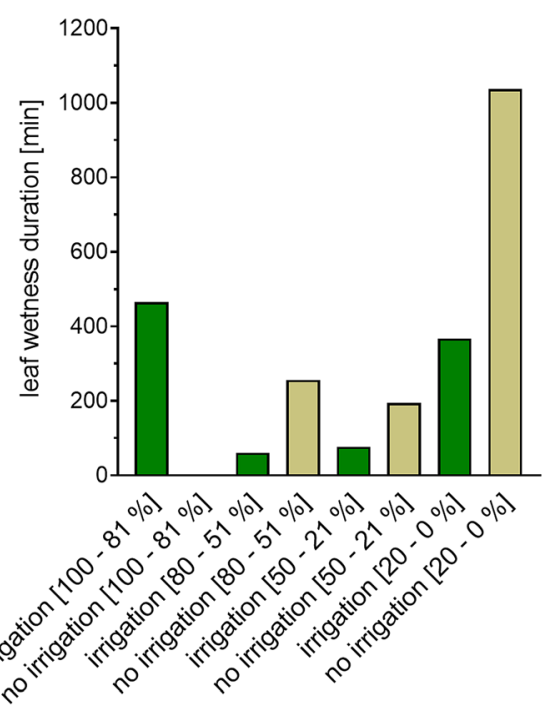

B

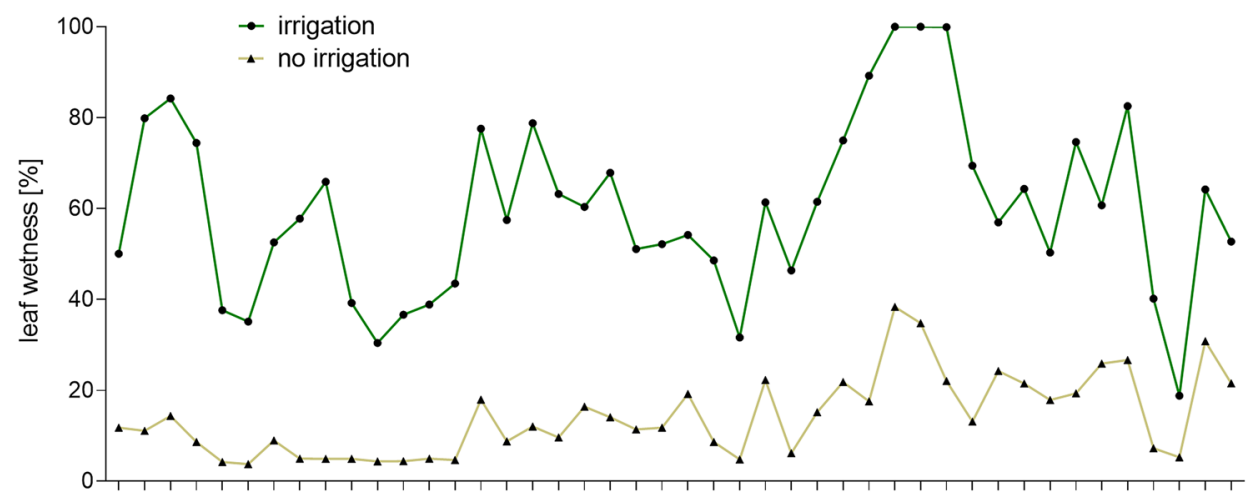

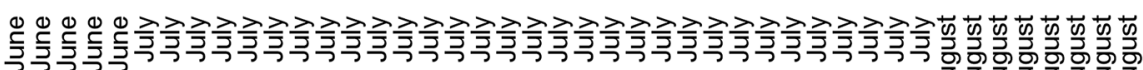

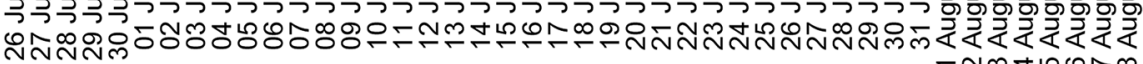
ธํํㅇํㅇํㅇㅇำ

Based on the collected data, we calculated a disease severity ranking (rank 1 to 15 for individual genotypes) (Fig. 6) The lowest mean ranking (highest disease resistance) was calculated for Grace (mean rank 5.2), followed by Eunova (mean rank 5.8), Romilda (mean rank 6.0), Umbrella (mean rank 6.25) and IPZ 24727 (mean rank 6.4). High mean rankings of Quench (mean rank 12.8), breeding line STRG 706/16 (mean rank 12.6) and Aischa (mean rank 10.8) indicated susceptibility to RLS.

\section{Monitoring of microclimate and weather conditions in the field trails}

For a better interpretation of disease severity and progression in the field, the microclimate within the canopy was monitored in the seasons 2017 to 2019 (Table 2). We recorded data during growth stages of booting and grain maturity parallel to the rainout shelter experiments. The mean temperature in the canopy near the ground was between $18.2^{\circ} \mathrm{C}$ (2018) and $20.7^{\circ} \mathrm{C}$ (2019). We recorded the highest mean temperature within canopy $\left(24.4^{\circ} \mathrm{C}\right)$ in the first week of July in 2019. Total average air humidity within the plots was $75.1 \%$ (2017), $82.0 \%$ (2018) and 79.8\% (2019). The mean dew point temperature was in accordance with temperature and relative air humidity.

We further collected weather data from a nearby weather station for the years 2016-2019. For details of the seasonal weather conditions in respect to average monthly temperature, average monthly precipitation, average monthly leaf wetness and average monthly radiation, we refer to supplemental Tables S3 to S6. 
Fig. 5 Levels of Ramularia leaf spot infestation according to assessed disease parameters in the field trials between 2016 and 2019. The bars indicate calculated mean values; symbols indicate single values. a represents percentage of leaf area with Ramularia and physiological leaf spots in the years 2016 to 2019. $\mathbf{b}$ indicates percentage of leaf area with sporulation in 2018 and 2019. c Content of Ramularia-DNA in pg Rcc DNA/ng total DNA in the upper leaves in 2018 and 2019
A

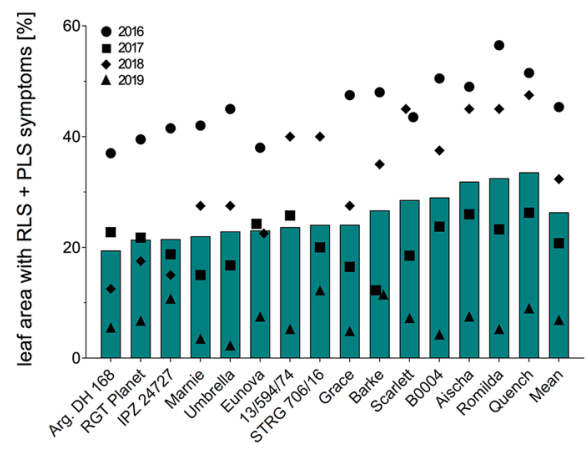

C

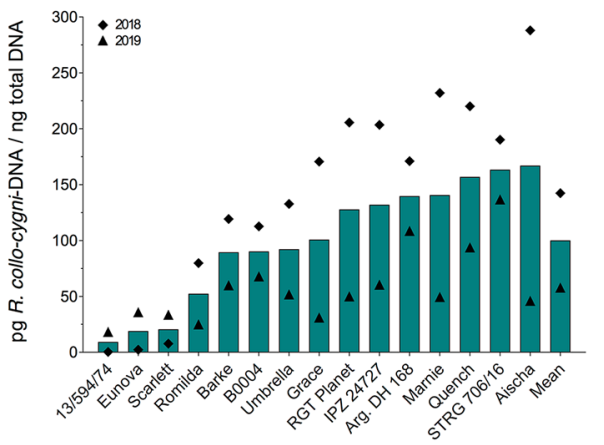

B

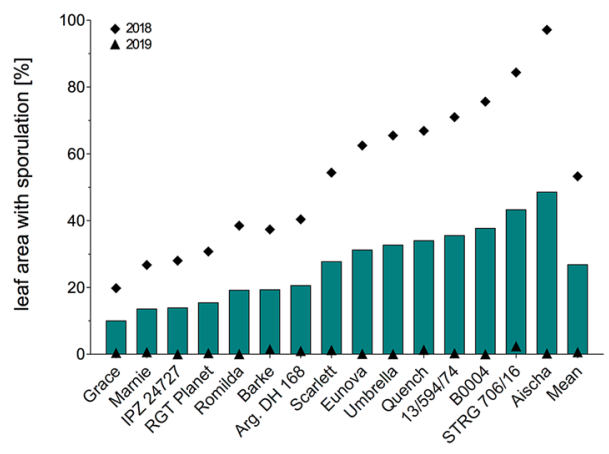

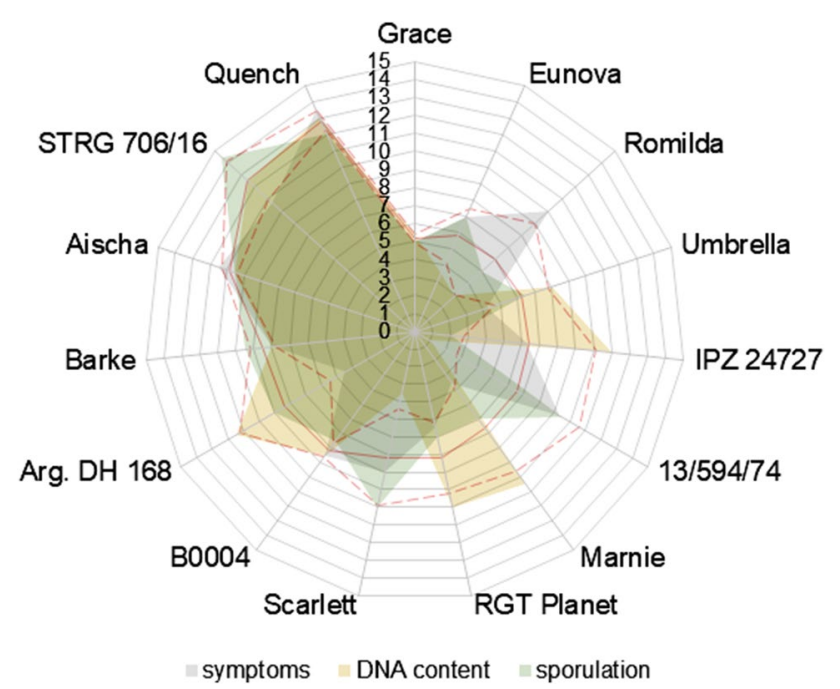

Fig. 6 Disease severity ranking according to assessed disease parameters in the field trials between 2016 and 2019. The radar plot shows mean ranks for each disease parameter. The red lines indicate the total mean rank over individual years and disease parameters $(n=8$ ranks per genotype); dashed lines indicate positive and negative standard deviation. The genotypes are sorted clockwise by total mean rank whereby low ranks indicate quantitative resistance and high ranks indicate susceptibility to Ramularia leaf spot. Individual ranks are in a range of minimum 1 and maximum 15 . If two or more genotypes share the same rank, the same value was associated to those lines

\section{Correlation of leaf senescence and RLS disease parameter}

In parallel to RLS symptoms, we recorded leaf senescence in the rainout shelter and in the field. To assess a relation between leaf senescence and further ripening with RLS disease parameters, the obtained data of senescent leaf area and RLS disease was used to calculate Pearson's correlations for the rainout shelter experiment and field trials (Fig. S3). A positive significant correlation occurred between senescent leaf area and Ramularia-DNA in the irrigated plots of the rainout shelter. In the field trials, leaf senescence was significantly negatively correlated with RLS symptoms and sporulation but not with fungal DNA (Figs. S3c, f and i).

\section{Evaluation of genotype stability for yield parameters}

In order to determine the stability of genotypes according to yield parameters across environments a stability index (yield parameter stability index, YPSI) was calculated, based on data of yield, fraction of kernels with a size $>2.5 \mathrm{~mm}$, fraction of kernels with a size $>2.8 \mathrm{~mm}$ and thousand kernel weight (TKW) (Fig. 7). The lower the YPSI is the more stable was the performance of a certain genotype for the considered yield parameters over several environments. The cultivar Aischa and breeding line B0004 showed the highest stability (lowest YPSI) across the determined yield 
Table 2 Recorded microclimate of spring barley grown in field trials in 2017, 2018 and 2019. The data were collected by data logger placed in a radiation shield on the ground within the canopy (logging interval: $1 \mathrm{~h}$ ). The table shows weekly mean temperature and mean relative humidity between the 2 nd week of June and 4 th week of July. The temperature of dew point was automatically determined by the data logger based on temperature and relative humidity. Measurements were taken in time frames according to late growth stages (booting to grain maturity)

\begin{tabular}{|c|c|c|c|c|c|c|c|c|c|}
\hline & \multicolumn{3}{|c|}{ Temperature $\left[{ }^{\circ} \mathrm{C}\right]$} & \multicolumn{3}{|c|}{ Relative humidity [\%] } & \multicolumn{3}{|c|}{ Dew point $\left[{ }^{\circ} \mathrm{C}\right]$} \\
\hline & 2017 & $2018^{*}$ & 2019 & 2017 & $2018^{*}$ & 2019 & 2017 & $2018^{*}$ & 2019 \\
\hline 2nd week of June & 16.6 & & 19.5 & 83.5 & & 76.8 & 13.3 & & 14.9 \\
\hline 3rd week of June & 19.9 & 18.0 & 19.9 & 70.0 & 85.0 & 87.7 & 13.6 & 15.3 & 17.4 \\
\hline 4th week of June & 22.5 & 17.2 & 21.4 & 67.7 & 79.5 & 87.1 & 15.5 & 13.4 & 18.6 \\
\hline 1st week of July & 20.6 & 17.2 & 24.4 & 77.2 & 84.2 & 75.8 & 15.9 & 14.1 & 19.1 \\
\hline 2nd week of July & 21.1 & 18.7 & 21.0 & 73.4 & 80.7 & 75.1 & 15.4 & 14.9 & 15.6 \\
\hline 3rd week of July & 19.8 & 18.4 & 18.2 & 82.1 & 80.6 & 81.9 & 16.0 & 14.5 & 14.5 \\
\hline 4th week of July & 21.6 & 19.6 & 20.5 & 71.0 & 82.8 & 75.6 & 15.1 & 15.9 & 15.4 \\
\hline average & 20.4 & 18.2 & 20.7 & 75.1 & 82.0 & 79.8 & 15.1 & 14.7 & 16.4 \\
\hline
\end{tabular}

* Recording of microclimate was started in the $3^{\text {rd }}$ week of June in 2018

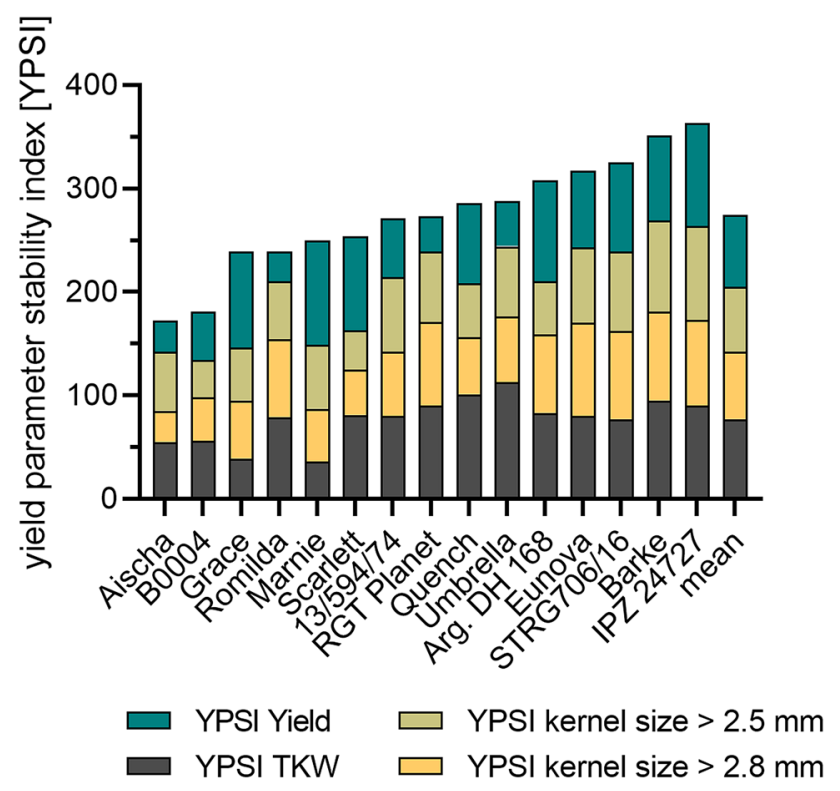

Fig. 7 Yield parameter stability index [YPSI] calculated for the assessed yield parameter: yield, thousand kernel weight (TKW), kernel size fraction $>2.5 \mathrm{~mm}$ and kernel size fraction $>2.8 \mathrm{~mm}$. The yield parameters were determined at nine locations including the rainout shelter, field trial (Freising) and six additional field locations in 2018. YPSI of each genotype was summed up for all yield parameters. The genotype with the smallest YPSI was considered to be the best across yield parameters and different field locations

parameters (YPSI: 172; YPSI: 181), whereas IPZ 24727 (YPSI 363) and Barke (YPSI 351) were least stable. Total mean of YPSI over all 15 tested genotypes was 637.5. Marnie and Grace showed highest stability in thousand kernel weight (YPSI: 36; GSI: 39), and Romilda (YPSI: 29) and Aischa (YPSI: 30) for yield.

\section{Discussion}

Understanding the impact of environmental conditions on disease epidemics and on resistance of crop plants is crucial for development of multiple stress resistant genotypes under aspects of climate change. The aim of this study was to screen an assortment of spring barley genotypes for basal resistance against $R$. collo-cygni under natural, regularly irrigated and drought conditions in the field. Data show an interaction between drought and the RLS disease and differentiation of quantitative RLS resistance in spring barley genotypes. This may ease future choice of cultivars by farmers and support efforts to breed for RLS resistance.

The rainout shelter experiment provided data about genotype performance and RLS resistance under both, drought conditions and irrigation over three consecutive field seasons. The obtained data revealed a clear differentiation in disease severity between the most resistant and most susceptible genotypes, especially in the irrigated plots. A few genotypes showed a reproducible quantitative RLS resistance over three consecutive years. Furthermore, the tested genotypes represent a diverse set of largely modern barley cultivars commonly grown in Europe and current breeding material from German barley breeders. Hence, data identify available cultivars directly recommendable for practical farming, although, of course, even more RLS-resistant genotypes might be available that have not been tested here.

The genotypes IPZ 24727, Grace, Umbrella and Eunova exhibited little symptoms, sporulation and low fungal DNA contents in the upper leaves both in the irrigated situation and under drought stress. This resulted in less variations in assessed disease parameters and further very uniform genotype ranks across the consecutive seasons. This indicates a robust and drought stress-independent level of quantitative resistance against RLS disease. Apart from these cultivars, 
the effect of the environment on other genotypes tended to be intense. High year-to-year differences in leaf spotting, sporulation and DNA contents (Fig. 1b, d and f) suggest that uncontrolled weather parameters and potentially spore flight influenced disease severity particularly in more susceptible genotypes. In particular, disease severity was highest in 2016, where weather conditions were different from the following years (e.g. cooler weather conditions (Table S3). To balance the high variation in disease severity between the years, we calculated ranks for each disease parameter and a mean ranking for RLS resistance for each genotype (Fig. 3). According to our data, the ranking revealed a reproducible quantitative RLS resistance (e.g. breeding line IPZ 24727, cultivar Umbrella), or susceptibility (e.g. cultivar Scarlett), respectively, of several genotypes under irrigation and drought conditions. Hence, the ranking is an applicable approach to assess resistance obtained from different diagnostic tools for the selection of genotypes over several seasons, despite high year-to-year variation in obtained data. Furthermore, some genotypes referred as susceptible under irrigation were less affected by RLS under drought stress, e.g. cultivar Barke and Quench, which is represented by appropriate rankings (Fig. 1, 3). It should be noted, that the quantitative RLS resistance and susceptibility reported here was stable over several seasons for several genotypes, but we cannot predict whether this would generally occur at other locations (compare also field and rainout shelter ranks of certain lines such as Scarlett (Fig. 3, 6)). The strong impact of weather and possibly microclimate conditions on the RLS disease may also lead to unexpected environment-genotype interactions under conditions not tested here. Hence, further disease monitoring of a diverse panel of genotypes and at diverse locations appears recommendable for breeders and consultants.

Dry conditions in the rainout shelter were unfavourable for the development of RLS. Possibly, spore germination, infection through stomata and proliferation of $R$. collo-cygni were suppressed. Duration of stomata closure as a response to drought stress might have an impact on the rate of secondary infections by Ramularia conidia, which was shown to be important for pathogenesis (Stabentheiner et al. 2009). We further speculate that under prolonged drought conditions, the accelerated senescence of the host plant could have limited the time for successful pathogenesis of RLS. Under the applied extreme permanent drought conditions, plant development until full ripening occurred faster, which may have interfered with pathogen colonization and development of symptoms of the infected leaf tissue. This may occur despite the fact that plant stress can also support the disease, potentially by weakening the host (Schützendübel et al. 2008). For the $R$. collo-cygni-barley pathosystem, it is stated that host plant ontogenesis is directly linked to disease progression (Schützendübel et al. 2008; Havis et al. 2015), which is contrasting to adult plant resistance that is e.g. observed in selected cereal genotypes to powdery mildew and other diseases (Develey-Rivière and Galiana 2007). It seems possible, that the pathogen life style switch, from endophytic to necrotrophic, could not occur under heavy drought conditions. Drought stress may have modified plant physiology, possibly in a way that the fungus could hardly benefit from quickly senescing host tissue, though it has a necrotrophic growth potential and is even able to induce accelerated leaf senescence (Sjokvist et al. 2019). We further speculate that premature senescence under drought conditions inhibits the formation of typical necrotic spots, because total leaf necrosis as a response to drought occurred before the pathogen could induce local cell chlorosis and subsequent necrosis in the leaf tissue. Severe drought thus caused relatively RLSsymptomless but senescent leaves, even though the pathogen was present at a low level. As a response to drought, an accelerated remobilization of nutrients from leaves to generative organs (Zimmermann and Zentgraf 2005) could have withdrawn resources from infected leaf tissue and thereby limited access of $R$. collo-cygni to nutrient supply. This might have affected RLS symptoms and sporulation, but not fungal DNA in upper leafs of drought-stressed plants. In addition, correlations between leaf senescence and RLS disease parameter were contrasting in the irrigated plots and in our field trials, which makes a clear interpretation of the data difficult and requires more specific studies. Furthermore, responses to drought and heat at a cellular level, e.g. osmotic adjustment (Blum 2017), plant stress altered hormone signalling, formation of reactive oxygen species (Chaves et al. 2003; Zimmermann and Zentgraf 2005) or accumulation of antioxidants (Sallam et al. 2019) could probably impair development of $R$. collo-cygni resulting in less disease progression.

In context of RLS, it is not fully clear from literature, whether barley physiologically exhibits an age-related susceptibility to RLS independent of additional exposure to stress, e.g. by a metabolic switch to the generative development. Alternatively, the pathogen could exploit a weakened host that faces multiple stresses late in the season and hence exerts host stress-dependent virulence. There is considerable evidence that age-related physiological alterations including the breakdown of the antioxidative system within host tissue increases the imbalance between symptomless pathogen development and the active plant defence system (Heiser et al. 2003; Miethbauer et al. 2006; Schützendübel et al. 2008), resulting in a typical late but rapid outbreak of RLS disease. That most probably holds true under normal field conditions, but is strongly modulated under heavy and prolonged drought stress with accelerated ripening and plant senescence. Less spotted leaf area and fungal DNA contents in leaves of drought-stressed plants provide evidence for a suppression of RLS disease under unfavourable 
environmental conditions supporting accelerated plant death (Fig. 1, S2 and S4). It remains unclear, why physiological leaf spots (PLS) were also considerably less frequent on drought-stressed plants. We found a general reduction in leaf spotting including PLS on all drought-stressed genotypes, even though plants normally show a higher expression of PLS caused by stress related oxidative disorder in leaf tissue (Wu and von Tiedemann 2002). We cannot exclude that a single and early fungicide application conducted in the rainout shelter experiment had an effect on plant physiology, which could have further affected PLS incidence. In general, fungicides alter plant physiology by reducing oxidative stress in leaf tissue and further affect the formation of PLS (Wu and von Tiedemann 2002). However, all plots were similarly cover-sprayed long before drought stress was induced, so that interactions between fungicide activity and plant stress physiology might have been overlain by increasing drought stress. On the other hand, the tested genotypes were partially preselected for their adaptation to environmental stress, including less leaf spotting in general, which could explain lower expression of leaf spots than expected from an unbiased assortment. Furthermore, our data supports previously reported genotype-dependent expression of leaf spots (Wu and von Tiedemann 2004). Nevertheless, it is still not clear, whether an increase in plant stress enhances RLS or is a result of RLS disease and hence is maybe involved in pathogenesis (McGrann et al. 2015). Furthermore, a survey of McGrann et al. (2015) demonstrated that a stress-responsive $\mathrm{NACl}$ gene transcription factor involved in drought tolerance and plant development is affecting susceptibility to RLS. NACl over-expression lines, which are more drought tolerant, simultaneously exhibited less leaf senescence, less RLS symptoms and fungal DNA in barley leaves, which further connects abiotic stress resistance and RLS resistance. By contrast, our data did not reveal a fully conclusive picture of correlation of genotype-dependent leaf senescence or green leaf area in upper leaves during ripening and RLS disease parameters in the rainout shelter when compared to the field (Figs. S2, S3 and S4). At the moment we can only speculate that on the one hand, more fungal biomass in upper leaves has contributed to accelerated leaf senescence in the rainout shelter. On the other hand, early senescence in the field might have limited symptom formation and fungal sporulation (Fig. S3c, f). The future question arises whether there is a trade-off between resistance to RLS and late plant ripening. The longer leaves can maintain their function to provide assimilates and do not become senescent, the more yield is potentially produced (Gregersen et al. 2008). Prolonged juvenility might support resilience to environmental stress situations, but could also be exploited by the partially endophytic fungus to complete its life cycle. Our data on stability of yield parameters across several environments (including the rainout shelter and our field trials) (Fig. 7) suggest that there are a few genotypes that are comparably resistant to RLS and show a high yield stability (e.g. Grace, Romilda). However, the moderatley RLS-resistant genotype IPZ 24727 revealed low stability of yield parameters over diverse field environments. Additionally, Scarlett and B0004 are comparably susceptible to RLS but still show high yield. Furthermore, the data suggests that such genotypes would perform in a same manner in other locations when field and weather conditions are predominantly comparable. Hence, genotypes with a high yield stability and RLS resistance across several different environments are recommendable for most barley cropping areas. However, different drought stress scenarios (e. g. drought stress during early growth stages or prior to flowering) could change RLS incidence and genotype performance. Therefore, further studies on different drought conditions in the field are necessary to estimate the impact on epidemics, genotype-dependent RLS resistance and stability of yield parameters. Taken together, the question arises whether there might be a trade-off between genotype-dependent ripening, yield performance and disease resistance, which should be taken into account by research and plant breeders. In this context, disease tolerance under variable environmental conditions, instead of resistance, could become a potential breeding aim.

Rainfalls, air humidity, and leaf wetness duration are generally important for the dispersal, infection, latency period, and proliferation of several plant pathogens caused such as Pyrenophora teres (Shaw 1986). Several studies indicated that moisture seems to have a high impact on epidemics of RLS, too (Formayer et al 2002; Mařík et al. 2011; Brown et al. 2014; Havis et al. 2015). According to observations of Formayer et al. (2002), artificial prevention of leaf wetness strongly decreased symptom formation under semi-controlled conditions in the field, whereas leaf wetness from dew was sufficient for disease development. Brown et al. (2014) found a positive relationship between area under RLS disease progress curve and leaf wetness at different locations and over several years. The results are in line with our own findings in the rainout shelter experiment, where plants were not irrigated from the booting stage till harvest and further experienced increasing drought conditions (Fig. S1). Hence, leaf wetness exclusively originated from air humidity during the night and at low level. Furthermore, under such conditions duration of leaf wetness was shortened, which might have limited spore germination and fungal growth on leaf surfaces (Fig. 4; Table 1). Microclimatic measurements revealed that relative air humidity within canopy of drought-stressed plants was continuously decreased, while temperature was increased when compared to irrigated plots (Table 1). Consequently, leaf wetness and duration of leaf wetness were strongly reduced within the dry canopy. Simultaneously, conidiophores and conidia were hardly present on senescent leaves of drought-stressed barley. This 
implies that the extent and duration of remaining leaf wetness was likely insufficient for the pathogen to complete its life cycle. The same could hold true for spore germination and early colonization from air borne inoculum. Results by Havis et al. (2012) showed, that an increase in leaf wetness was followed by a massive release of spores into the air. By contrast, Schützendübel et al. (2008) observed two peaks of airborne spores in one winter barley trial during a dry period late in the season and independently from rainfall events. Hence, spore formation may primarily depend on sufficient air humidity and dew, but rain events may act as an enhancing factor. According to a study by Mařík et al. (2011), variable pattern of rainfall post flowering seems to have a high impact on RLS incidence. They observed that a stronger disease progression in a collection of winter barley genotypes occurred in seasons with more rainy days and lower temperatures, which enabled favourable conditions for the fungus. Despite the increased temperature in droughtstressed canopy, a direct effect of temperature on RLS is not obvious in our data, but may have further shortened duration of leaf wetness. Taken together, our data supports the importance of moisture for sporulation of $R$. collo-cygni and shows a strong suppression of RLS development under long-lasting drought conditions.

In addition to drought stress experiments in the rainout shelter, the spring barley genotypes were patho-phenotyped in parallel field trials over 4 years (2016-2019). In general, disease incidence varied between seasons and revealed a high level of symptoms, sporulation and fungal DNA contents in upper leaves, thus indicating strong natural disease pressure at the location. At late growth stage 83-85, RLS and PLS formed the predominant foliar disease ahead of net blotch and brown rust (Fig. S4), but differences in symptomatic leaf areas between genotypes were less noticeable when compared to the rainout shelter (Fig. 1). The assessment of fungal sporulation and determination of Ramularia-DNA revealed stronger differences in resistance to $R$. collo-cygni between the tested spring barley genotypes compared to the rainout shelter experiment (Figs. 1, 5). However, it is difficult to assess field resistance to RLS from single factors, e.g. symptom monitoring without determination of fungal DNA contents. Hence, the applied diagnostic tools complement each other and increased robustness of field data. Based on the three recorded disease parameters, a calculation of mean ranks revealed comparable disease resistance of several genotypes in both open field and rainout shelter experiments. Thus, scoring of RLS parameters under field conditions confirmed resistance of several genotypes that was observed under semi-controlled conditions in the rainout shelter (e.g. IPZ 24727, Grace, Eunova and Umbrella). Furthermore, measurements of meteorological factors including temperature, precipitation and relative air humidity on site and by a nearby weather station revealed mainly similar conditions in the field trials compared to the irrigated plots in the rainout shelter experiment. By contrast, leaf wetness was higher in the rainout shelter than in the field during the recorded period (Fig. 4, Table S5), probably due to weekly irrigation of $20 \mathrm{~mm}$. By comparing disease parameters with weather conditions of individual field seasons, there was no clear interaction between warm and dry conditions and RLS severity. Highest RLS severity across all disease parameter was observed in 2016, where temperatures were cooler than in the following seasons. RLS severity was indeed lower in the warmer and dryer years 2017 and 2019, but not in 2018. In fact, very hot periods after barley flowering stage in June and July 2018 were intermitted by single rain events, possibly allowing for strong disease progression. Hence, single rain events could likely provoke sufficiently moist conditions and may enable strong disease outbreaks post flowering by suspending periods with unfavourable conditions. Furthermore, high air humidity during the night enhances leaf wetness by dew formation, which we could observe in particular in our field trials in 2018. However, climate change will likely cause more drought periods in central Europe and Germany (Zebisch et al. 2005), and thus will further affect plant diseases. For the case of RLS, our findings suggest that dry and hot conditions could suppress RLS disease in years with very long-lasting lack of rain. However, there are also reasons to assume that single rain events in dry summers such as 2018 are sufficient to support RLS disease of pre-stressed plants.

To meet the challenge of better understanding the complex interaction of host genotypes, environment and disease progression, this study provides a first insight into multiple stress resistance of barley under aspects of a changing climate. Further experiments from controlled and complex environments may help future prediction of RLS disease dependent on the cultivar and seasonal weather conditions. Our data are relevant for crop production and future breeding of robust and resilient crop plants. In particular, the current lack of effective fungicides to control RLS reinforces the importance of resistance breeding and the choice of quantitative RLS-resistant barley cultivars. Indeed, we identified a set of spring barley genotypes that were quite resistant to RLS under three different field environments in three years of investigation.

\section{Conclusion}

Since the 1980s, Ramularia collo-cygni became a major pathogen in barley production around the world. The possible connection between disease progression, environmental conditions and plant maturity is still not fully 
understood. Genetic resistance of barley to RLS is limited and hardly exploited. The present study describes suppressive effects of strong drought conditions on RLS severity of a preselected panel of spring barley genotypes. We identified genotypes with a reliable resistance to RLS disease in a multi-annual study under controlled drought, irrigated and natural conditions in the field. The results support that RLS depends on moisture and is suppressed under persistent drought conditions that rarely occur under open field conditions. Parallel field trials during very warm and dry seasons suggest that the formation of dew and single rain events still suffice for considerable RLS disease outbreaks. Moreover, our investigations contribute to a better general understanding of interactions between environmental factors and the epidemics of RLS. Based on our experience, we further recommend using complementary diagnostic tools for phenotyping of barley RLS resistance.

Supplementary file 1 (PDF 679 kb)Supplementary information The online version of this article (https://doi.org/10.1007/s41348-02000420-z)

Acknowledgements We thank the Ackermann Saatzucht GmbH \& Co. KG (Irlbach, Germany), Saatzucht Josef Breun GmbH \& Co. KG (Herzogenaurach, Germany) and Saatzucht Streng-Engelen GmbH \& Co. KG (Uffenheim, Germany) for good corporation and providing and propagating seed material. We are grateful to Dr. Anja Hanemann (Saatzucht Breun GmbH \& Co. KG), Christian Schuy (Friedrich-Alexander University Erlangen-Nürnberg) and Prof. Dr. Lars Voll (Philipps University of Marburg) for their comprehensive support in selecting barley genotypes. The authors thank the field technician team of the greenhouse and laboratory centre Dürnast (Technische Universität München) and the field technician team of the Bavarian State Institute of Crop Science and Plant Breeding in Freising for maintenance of field experiments. We also want to thank Carolin Hutter, Alice Retter and Bianca Eibl for technical support.

Funding Open Access funding enabled and organized by Projekt DEAL.. Open Access funding enabled and organized by Projekt DEAL.. This project was financially supported by the Bavarian State Ministry of the Environment and Consumer Protection in frame of the Project network BayKlimaFit (www.bayklimafit.de); subproject 10: TGC01GCUFuE69781.

\section{Compliance with ethical standards}

Conflict of interest The authors declare that they have no conflict of interest.

Ethical approval This article does not contain any studies with human or animal subjects.

Open Access This article is licensed under a Creative Commons Attribution 4.0 International License, which permits use, sharing, adaptation, distribution and reproduction in any medium or format, as long as you give appropriate credit to the original author(s) and the source, provide a link to the Creative Commons licence, and indicate if changes were made. The images or other third party material in this article are included in the article's Creative Commons licence, unless indicated otherwise in a credit line to the material. If material is not included in the article's Creative Commons licence and your intended use is not permitted by statutory regulation or exceeds the permitted use, you will need to obtain permission directly from the copyright holder. To view a copy of this licence, visit http://creativecommons.org/licenses/by/4.0/.

\section{References}

Anderson PK, Cunningham AA, Patel NG, Morale FJ, Epstein PR, Daszak P (2004) Emerging infectious diseases of plants: pathogen pollution, climate change and agrotechnology drivers. Trends Ecol Evol 19(10):535-544

Apel K, Hirt H (2004) Reactive oxygen species: metabolism, oxidative stress, and signal transduction. Annu Rev Plant Biol 55:373-399

Atkinson NJ, Urwin PE (2012) The interaction of plant biotic and abiotic stresses: from genes to the field. J Exp Bot 63(10):3523-3543

Behn A, Hartl L, Schweizer G, Baumer M (2005) Molecular mapping of QTLs for non-parasitic leaf spot resistance and comparison of half-sib DH populations in spring barley. Euphytica 141(3):291-299

Blum A (2017) Osmotic adjustment is a prime drought stress adaptive engine in support of plant production. Plant Cell Environ 40(1):4-10

Brown JK., Havis ND, Fountaine JM, McGrann GR, Corbitt MM, Kaczmarek M, Oxley SJP, Piotrowska M, Russell J, Thomas WT (2014). Control of Ramularia leaf spot in a changing climate. Project Report No. 553

Cavara F (1893) Über einige parasitische Pilze auf dem Getreide. Z Für Pflanzenkrankh 3(1):16-26

Chakraborty S, von Tiedemann A, Teng PS (2000) Climate change: potential impact on plant diseases. Environ Pollut 108(3):317-326

Chaves MM, Maroco JP, Pereira JS (2003) Understanding plant responses to drought-from genes to the whole plant. Funct Plant Biol 30(3):239-264

Crossa J, Gauch HG, Zobel RW (1990) Additive main effects and multiplicative interaction analysis of two international maize cultivar trials. Crop Sci 30(3):493-500

Czembor JH, Czembor PC, Doraczyńska O, Pietrusińska A, RadeckaJanusik M (2016) Transfer of the mlo resistance gene into to the genome of winter barley. Prog Plant Prot 56(3):379-387

De Mendiburu F, Simon R (2015) Agricolae-10 years of an open source statistical tool for experiments in breeding, agriculture and biology (No. e1748). PeerJ PrePrints

Delgado-Baquerizo M, Guerra CA, Cano-Díaz C, Egidi E, Wang JT, Eisenhauer N, Singh BK, Maestre FT (2020) The proportion of soil-borne pathogens increases with warming at the global scale. Nature Clim Chang 1-5

Develey-Rivière MP, Galiana E (2007) Resistance to pathogens and host developmental stage: a multifaceted relationship within the plant kingdom. New Phytol 175(3):405-416

Dussart F, Douglas R, Sjökvist E, Hoebe PN, Spoel SH, McGrann GRD (2018) Genome-based discovery of polyketide-derived secondary metabolism pathways in the barley pathogen Ramularia collo-cygni. Mol Plant Microbe Interact 31(9):962-975

Fischbeck G (2002) Contribution of barley to agriculture: a brief overview. Barley science recent advances from molecular biology to agronomy of yield and quality. Food Products Press, New York, pp 1-29

Formayer H, Huss H, Eckhardt S, Gerersdorfer T, Kromp-Kolb H (2002) Die sprenkelkrankheit auf der gerste: untersuchung der meteorologischen ursachen der krankheit insbesondere der entwicklung des pilzes Ramularia collo-cygni. Endbericht des 
forschungsprojektes Nr. 1223 des BMLFUW Austria; online available: https://meteo.boku.ac.at/klima/berichte/Ramularia. pdf, last accessed 19 Mar 2020

Fountaine JM, Fraaije BA (2009) Development of QoI resistant alleles in populations of Ramularia collo-cygni. Asp of Appl Biol 92:123-126

Frei P, Gindro K, Richter H, Schürch S (2007) Direct-PCR detection and epidemiology of Ramularia collo-cygni associated with barley necrotic leaf spots. J Phytopathol 155(5):281-288

Gregersen PL, Holm PB, Krupinska K (2008) Leaf senescence and nutrient remobilisation in barley and wheat. Plant Biol 10:37-49

Havis ND, Oxley SJ, Piper SR, Langrell SR (2006) Rapid nested PCRbased detection of Ramularia collo-cygni direct from barley. FEMS Microbiol Lett 256(2):217-223

Havis ND, Oxley SJP, Burnett FJ, Hughes G (2012) Epidemiology of Ramularia collo-cygni. In: The dundee conference. Crop protection in northern britain, 2012, Dundee, UK (pp. 119-124). The association for crop protection in northern britain. 28-29 Feb 2012

Havis ND, Nyman M, Oxley SJP (2014) Evidence for seed transmission and symptomless growth of Ramularia collo-cygni in barley (Hordeum vulgare). Plant Pathol 63(4):929-936

Havis ND, Brown JK, Clemente G, Frei P, Jedryczka M, Kaczmarek J, Kaczmarek M, Matusinsky P, McGrann GR, Pereyra S, Piotrowska M, Sghyer H, Tellier A, Hess M (2015) Ramularia collo-cygni-an emerging pathogen of barley crops. Phytopathol 105:895-904

Havis ND, Gorniak K, Taylor J, Stanisz-Migal M, Burnett FJ (2018a) Controlling Ramularia leaf spot in barley crops. Proceedings crop production in northern britain 2018, Dundee, UK (pp. 91-96). The Association for Crop Protection in Northern Britain. 27-28 Feb 2018

Havis ND, Evans N, Hughes G (2018b). Development of UK wide risk forecast scheme for Ramularia leaf spot in barley. Project Report No. PR600

Heiser I, Sachs E, Liebermann B (2003) Photodynamic oxygen activation by rubellin $\mathrm{D}$, a phytotoxin produced by Ramularia collocygni (Sutton et Waller). Physiol Mol Plant Pathol 62(1):29-36

Heß M, Habeker R, Kick M, Martin M, Hausladen H (2007) Optimierte strategien zur krankheitsbekämpfung in der gerste unter berücksichtigung neuer erkenntnisse zur epidemiologie des blattfleckenkomplexes. Gesunde Pflanz 59(2):47-54

Hofer K, Linkmeyer A, Textor K, Hückelhoven R, Hess M (2015) MILDEW LOCUS O mutation does not affect resistance to grain infections with Fusarium spp and Ramularia collo-cygni. Phytopathology 105(9):1214-1219

Hofer K, Barmeier G, Schmidhalter U, Habler K, Rychlik M, Hückelhoven R, Hess M (2016) Effect of nitrogen fertilization on Fusarium head blight in spring barley. Crop Protect 88:18-27

Huss H. (2004). The biology of Ramularia collo-cygni. In: Yahyaou A, Brader L, Tekauz A, Wallwork H, Steffenson B (eds) Proceedings of the second international workshop on barley leaf blights. Aleppo, Syria: ICARDA, 321-8. 7-11 Apr 2002

Huss H (2008) Die sprenkelkrankheit nun auch auf Mais! Der Pflanzenarzt 61(11-12):6-7

Huss H, Miethbauer S (2010) Ramularia erobert roggen. Der Pflanzenarzt 63(8):9-10

Jørgensen IH (1992) Discovery, characterization and exploitation of Mlo powdery mildew resistance in barley. Euphytica 63(1-2):141-152

Juroszek P, von Tiedemann A (2013) Plant pathogens, insect pests and weeds in a changing global climate: a review of approaches, challenges, research gaps, key studies and concepts. J Agric Sci 151(2):163-188
Kaczmarek M, Piotrowska MJ, Fountaine JM, Gorniak K, McGrann GRD, Armstrong A, Wright KM, Newton AC, Havis ND (2017) Infection strategy of Ramularia collo-cygni and development of ramularia leaf spot on barley and alternative graminaceous hosts. Plant Pathol 66(1):45-55

Lanzinger A, Frank T, Reichenberger G, Herz M, Engel KH (2015) Metabolite profiling of barley grain subjected to induced drought stress: responses of free amino acids in differently adapted cultivars. J Agric Food Chem 63(16):4252-4261

Luck J, Spackman M, Freeman A, Tre. Bicki P, Griffiths W, Finlay K, Chakraborty S (2011) Climate change and diseases of food crops. Plant Pathol 60(1):113-121

Makepeace JC, Oxley SJP, Havis ND, Hackett R, Burke JI, Brown JKM (2007) Associations between fungal and abiotic leaf spotting and the presence of mlo alleles in barley. Plant Pathol 56(6):934-942

Makepeace JC, Havis ND, Burke JI, Oxley SJP, Brown JKM (2008) A method of inoculating barley seedlings with Ramularia collocygni. Plant Pathol 57(6):991-999

Mařík P, Šnejdar Z, Matušinsky P (2011) Expression of resistance to Ramularia leaf spot in winter barley cultivars grown in conditions of the Czech Republic. Czech J Genet Plant Breed 47(1):37-40

Matusinsky P, Svobodova-Leisova L, Mariks P, Tvaruzek L, Stemberkova L, Hanusova M, Minarikova V, Vysohlidova M, Spitzer $\mathrm{T}$ (2010) Frequency of a mutant allele of cytochrome b conferring resistance to Ool fungicides in the Czech population of Ramularia collo-cygni. J Plant Dis Prot 117(6):248-252

Matusinsky P, Leisova-Svobodova L, Gubis J, Hudcovicova M, Klcova L, Gubisova M, Marik P, Tvaruzek L, Minarikova V (2011) Impact of the seed-borne stage of Ramularia collo-cygni in barley seed. J Plant Pathol 679-689

McGrann GR, Havis ND (2017) Ramularia leaf spot: a newly important threat to barley production. Outlooks Pest Manag 28(2):65-69

McGrann GR, Stavrinides A, Russell J, Corbitt MM, Booth A, Chartrain L, Thomas WTB, Brown JK (2014) A trade off between mlo resistance to powdery mildew and increased susceptibility of barley to a newly important disease, Ramularia leaf spot. J Exp Bot 65(4):1025-1037

McGrann GR, Steed A, Burt C, Goddard R, Lachaux C, Bansal A, Corbitt M, Gorniak K, Nicholson P, Brown JK (2015) Contribution of the drought tolerance-related stress-responsive NAC1 transcription factor to resistance of barley to Ramularia leaf spot. Mol Plant Pathol 16(2):201-209

Miethbauer S, Heiser I, Liebermann B (2003) The phytopathogenic fungus Ramularia collo-cygni produces biologically active rubellins on infected barley leaves. J Phytopathol 151(11-12):665-668

Miethbauer S, Haase S, Schmidtke KU, Günther W, Heiser I, Liebermann B (2006) Biosynthesis of photodynamically active rubellins and structure elucidation of new anthraquinone derivatives produced by Ramularia collo-cygni. Phytochemistry 67(12):1206-1213

Newton AC, Fitt BD, Atkins SD, Walters DR, Daniell TJ (2010) Pathogenesis, parasitism and mutualism in the trophic space of microbe-plant interactions. Trends Microbiol 18(8):365-373

Newton AC, Flavell AJ, George TS, Leat P, Mullholland B, Ramsay L, Revoredo-Giha C, Russell J, Steffenson BJ, Swanston JS, Thomas WTB, Waugh R, White PJ, Bingham IJ (2011) Crops that feed the world 4. Barley: a resilient crop? strengths and weaknesses in the context of food security. Food Secur 3(2):141

Agrarmeteorologie Bayern (2019) Online available at: https://www. wetter-by.de/Internet/AM/inetcntrBY.nsf/cuhome.xsp?src=6J88S $16 \mathrm{AZG} \& \mathrm{p} 1=20 \mathrm{R} 4 \mathrm{O} 28 \mathrm{G} 53 \& \mathrm{p} 3=788 \mathrm{O} 2197 \mathrm{Z} 2 \& \mathrm{p} 4=4 \mathrm{D} 078$ O1691, last accessed 01 Apr 2020

Oxley SJP, Havis ND, Sutherland KG, Nuttall M (2002) Development of a rationale to identify the causal agent of necrotic lesions in 
spring barley and to identify control mechanisms. HGCA Project report

Pandey P, Ramegowda V, Senthil-Kumar M (2015) Shared and unique responses of plants to multiple individual stresses and stress combinations: physiological and molecular mechanisms. Front Plant Sci 6:723

Pinnschmidt HO, Jørgensen LN (2009) Yield effects of Ramularia leaf spot on spring barley. Asp Appl Biol 92:57-66

Pinnschmidt H, Sindberg S (2007). Expression of resistance of barley varieties to Ramularia leaf spot and the status of the disease in Denmark. In: Proceedings 1st European Ramularia Worksho. Germany, Göttingen (pp. 85-93)

Piotrowska MJ, Fountaine JM, Ennos RA, Kaczmarek M, Burnett FJ (2017) Characterisation of Ramularia collo-cygni laboratory mutants resistant to succinate dehydrogenase inhibitors. Pest Manag Sci 73(6):1187-1196

Purchase JL, Hatting H, Van Deventer CS (2000) Genotype × environment interaction of winter wheat (Triticum aestivum L.) in South Africa: II. Stability analysis of yield performance. South Afr J Plant Soisl 17(3):101-107

Fraaije BA, Lovell DJ, Rohel EA, Hollomon DW (1999) Rapid detection and diagnosis of Septoria tritici epidemics in wheat using a polymerase chain reaction/PicoGreen assay. J Appl Microbiol 86(4):701-708

Ramegowda V, Senthil-Kumar M (2015) The interactive effects of simultaneous biotic and abiotic stresses on plants: mechanistic understanding from drought and pathogen combination. J Plant Physiol 176:47-54

Rehfus A, Matusinsky P, Strobel D, Bryson R, Stammler G (2019) Mutations in target genes of succinate dehydrogenase inhibitors and demethylation inhibitors in Ramularia collo-cygni in Europe. J Plant Dis Prot 126(5):447-459

Reitan L, Salamati S (2006) Field screening in Norway for resistance to Ramularia collo-cygni in old and new barley material. In: proceedings 1st European Ramularia Workshop, Germany, Göttingen (pp. 73-82)

Sachs E (2006) The history of research into Ramularia leaf spot on barley. In: proceedings 1st European Ramularia workshop, Germany, Göttingen (pp. 9-15)

Sallam A, Alqudah AM, Dawood MF, Baenziger PS, Börner A (2019) Drought stress tolerance in wheat and barley: advances in physiology, breeding and genetics research. Int J Mol Sci 20(13):3137

Schützendübel A, Stadler M, Wallner D, Von Tiedemann A (2008) A hypothesis on physiological alterations during plant ontogenesis governing susceptibility of winter barley to ramularia leaf spot. Plant Pathol 57(3):518-526

Sghyer H, Hess M (2019) Culture conditions influence conidial production by the barley pathogen Ramularia collo-cygni. J Plant Dis Prot 126:319-327

Shaw MW (1986) Effects of temperature and leaf wetness on Pyrenophora teres growing on barley cv. Sonja Plant pathol 35(3):294-309
Sjokvist E, Lemcke R, Kamble M, Turner F, Blaxter M, Havis NH, Lyngkjær MF, Radutoiu S (2019) Dissection of Ramularia leaf spot disease by integrated analysis of barley and Ramularia collo-cygni transcriptome responses. Mol Plant Microbe Interact 32(2):176-193

Stabentheiner E, Minihofer T, Huss H (2009) Infection of barley by Ramularia collo-cygni: scanning electron microscopic investigations. Mycopathologia 168(3):135

Stam R, Sghyer H, Tellier A, Hess M, Hückelhoven R (2019) The current epidemic of the barley pathogen Ramularia collo-cygni derives from a population expansion and shows global admixture. Phytopathology 109(12):2161-2168

Sutton BC, Waller JM (1988) Taxonomy of Ophiocladium hordei, causing leaf lesions on triticale and other Gramineae. Trans $\mathrm{Br}$ Mycol Soc 90(1):55-61

Taylor JMG, Paterson LJ, Havis ND (2010) A quantitative real-time PCR assay for the detection of Ramularia collo-cygni from barley (Hordeum vulgare). Lett Appl Microbiol 50(5):493-499

Walters DR, Havis ND, Oxley SJ (2008) Ramularia collo-cygni: the biology of an emerging pathogen of barley. FEMS Microbiol Lett 279(1):1-7

West JS, Townsend JA, Stevens M, Fitt BD (2012) Comparative biology of different plant pathogens to estimate effects of climate change on crop diseases in Europe. Eur J Plant Pathol 133(1):315-331

Wu YX, von Tiedemann A (2002) Evidence for oxidative stress involved in physiological leaf spot formation in winter and spring barley. Phytopathology 92(2):145-155

Wu YX, von Tiedemann A (2004) Light-dependent oxidative stress determines physiological leaf spot formation in barley. Phytopathology 94(6):584-592

Xie W, Xiong W, Pan J, Ali T, Cui Q, Guan D, Meng J, Davis SJ (2018) Decreases in global beer supply due to extreme drought and heat. Nature plants 4(11):964-973

Zebisch M, Grothmann T, Schröter D, Hasse C, Fritsch U, Cramer W (2005) Climate change in Germany_vulnerability and adaptation of climate sensitive sectors (Klimawandel in Deutschland-vulnerabilität und anpassungsstrategien klimasensitiver systeme). Report commissioned by the Federal Environmental Agency, Germany (UFOPLAN 20141 253), Potsdam Institute of Climate Impact Research, Potsdam, Germany

Zimmermann P, Zentgraf U (2005) The correlation between oxidative stress and leaf senescence during plant development. Cell Mol Biol Lett 10(3):515

Publisher's Note Springer Nature remains neutral with regard to jurisdictional claims in published maps and institutional affiliations. 